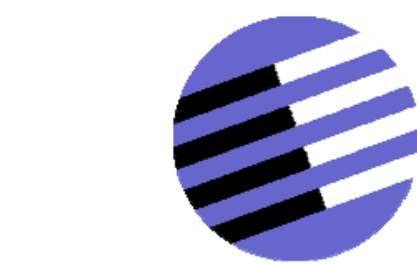

GOVERNANCE AND THE EFFICIENCY

OF ECONOMIC SYSTEMS

GESY

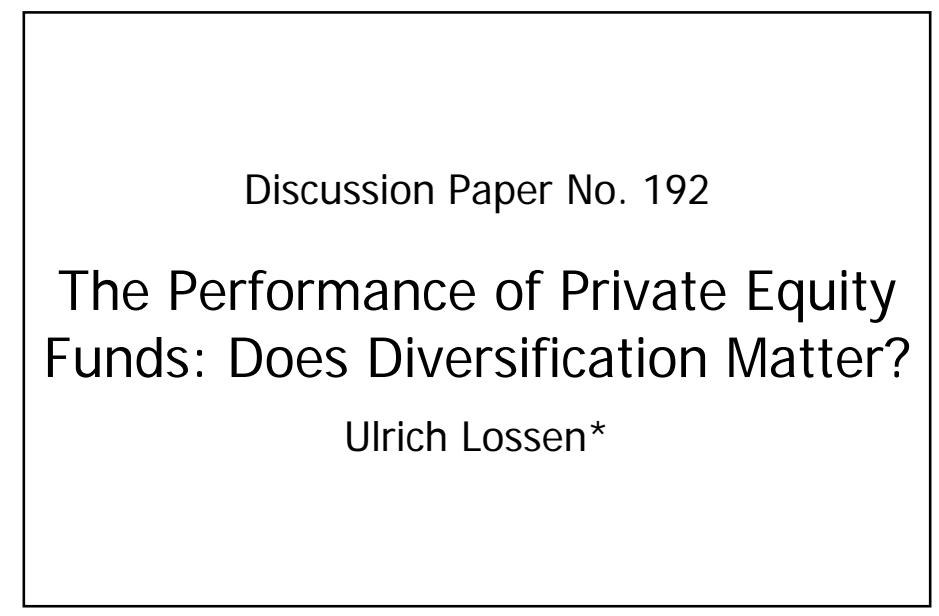

June 2006

*Ulrich Lossen, Munich School of Management, Institute for Innovation Research, Technology Management and Entrepreneurship. lossen@bwl.uni-muenchen.de

Financial support from the Deutsche Forschungsgemeinschaft through SFB/TR 15 is gratefully acknowledged. 


\title{
The Performance of Private Equity Funds: Does Diversification Matter?*
}

\author{
Ulrich Lossen ${ }^{\dagger}$
}

June 2006

\begin{abstract}
This paper is the first systematic analysis of the impact of diversification on the performance of private equity funds. A unique data set allows the exact evaluation of diversification across the dimensions financing stages, industries, and countries. Very different levels of diversification can be observed across sample funds. While some funds are highly specialized others are highly diversified. The empirical results show that the rate of return of private equity funds declines with diversification across financing stages, but increases with diversification across industries. Accordingly, the fraction of portfolio companies which have a negative return or return nothing at all, increase with diversification across financing stages. Diversification across countries has no systematic effect on the performance of private equity funds.
\end{abstract}

Keywords: private equity, diversification, specialization, performance, rate of return, percentage of loss

JEL Classifications: G11, G24, M13

*Acknowledgements: I gratefully thank Dietmar Harhoff, Joachim Henkel, Christoph Kaserer, Josh Lerner, Antoinette Schoar, and Stefan Wagner for valuable comments and discussions. Financial support from the Deutsche Forschungsgemeinschaft through SFB/TR 15 and the German Academic Exchange Service is gratefully acknowledged. All errors are my own. This paper critically depended on the access to confidential data on private equity funds. I wish to thank the managing partners of the fund-of-funds investor for their trust and willingness to support my research. I would like to note, that several precautions are made to secure the anonymity of the fund-of-funds investor as well as the PE firms, funds and portfolio companies included in the sample. The tables presented in this paper do not enable reverse identification of a single PE firm, fund or portfolio company.

†Ulrich Lossen, Munich School of Management, Institute for Innovation Research, Technology Management and Entrepreneurship, lossen@bwl.uni-muenchen.de 


\section{Introduction}

Over the last three decades, the global private equity (PE) industry has experienced an enormous growth. According to statistics of Thomson Venture Economics (TVE) new funds raised by PE firms worldwide have grown from USD 1.7 billion in 1976 to USD 192.3 billion in 2005, with a peak of USD 260.6 billion in 2000. Accordingly, there is a large and growing literature analyzing the return of PE investments (Jones \& Rhodes-Kropf 2003, Ljungqvist \& Richardson 2003a, Ljungqvist \& Richardson 2003b, Kaserer \& Diller 2004b, Gottschalg, Phalippou \& Zollo 2004, Cumming \& Walz 2004, Cochrane 2005, Kaplan \& Schoar 2005). The majority of these articles study the relative performance of PE compared to public markets. However, there is much less understanding about the impact of diversification on the performance of PE funds. In this paper, I try to fill this gap by examining the impact of diversification on the rate of return and the percentage of loss of PE funds.

PE firms are able to diversify their funds across five dimensions: (1) 'naive' diversification across the number of portfolio companies, (2) 'dynamic' diversification across time, 'systematic' diversification across (3) financing stages, (4) industries, and (5) countries. While 'naive' diversification only counts the number of portfolio companies in a PE fund, 'systematic' diversification takes into account the specific characteristics of portfolio companies. Diversification across time adds a dynamic perspective to account for changes in the economic conditions over the lifetime of a PE fund.

The decision determining the composition of a PE fund and thus the level of diversification, plays a crucial role in the formation of a $\mathrm{PE}$ fund. It is a long term strategic decision that is difficult to change. The maximum amount a PE fund is allowed to invest in a single company as well as in certain financing stages, industries, or countries is fixed in the partnership agreement with the limited partners, i.e., the investors. A deviation from this agreement is only possible if all limited partners approve.

1 Thomson Venture Economics is a commercial provider of $\mathrm{PE}$ information. It runs one of the largest databases on PE: VentureXpert. For more information, go to www.ventureeconomics.com. 
The selection and oversight of private companies is characterized by serious information asymmetries and principal agent conflicts (Chan 1983, Amit, Brander \& Zott 1998). As a result, PE firms specialized on certain financing stages, industries, and countries are expected to make superior selection decision and to add more value to their portfolio companies compared to diversified PE firms. This should turn into higher rates of return and smaller percentages of loss of specialized PE funds relative to diversified PE funds.

In this paper, I evaluate the impact of diversification on the rate of return and the percentage of loss of $\mathrm{PE}$ funds at the level of $\mathrm{PE}$ funds, because investors invest their capital in PE funds; neither in portfolio companies, nor in PE firms. An unique data set is utilized in order to analyze the impact of diversification on the performance of $\mathrm{PE}$ funds. The data distinguishes itself from data sets used in previous studies through its high level of detail. It includes information related to $100 \mathrm{PE}$ funds containing a detailed description of 2,871 portfolio companies and the complete cash flow histories between the portfolio companies and their funds. For the first time, the data allows the exact evaluation of the diversification levels of PE funds.

Very different levels of diversification can be observed across the sample of 100 PE funds. Some PE funds are highly specialized, whereas others are highly diversified. For instance, the least diversified PE fund in the sample at hand invests only in one financing stage, three industries, and one country. In contrast, the most diversified PE fund includes portfolio companies in three financing stages, seven industry segments, and 16 countries.

Controlling for a variety of variables, the multivariate regression analysis shows only partial evidence in favor of specialized PE funds compared to diversified PE funds. Although the rate of return of a PE fund is declining with the level of diversification across financing stages, it is increasing with diversification across industries. Diversification across countries appears to have no effect on the return of PE funds. The results suggest that the advantage of specialized PE firms to overcome the information asymmetries and principal agent problems inherent in the selection and oversight of private companies have been overestimated in the past. PE firms specialized in specific industries or countries do not seem to make 
superior selection decisions or to provide their portfolio companies with more value adding services than diversified PE firms. In contrast, the costs of diversification across financing stages appear to be quite high. An increase in diversification across financing stages by one standard deviation around its mean is connected with a decline of internal rate of return by 6.5 percentage points, ceteris paribus.

Accordingly, the percentage of loss, i.e., the fraction of portfolio companies in a fund which return less than $0 \%$, and the percentage of total loss, i.e., the fraction of portfolio companies which return $-100 \%$, increase with the level of diversification across financing stages. PE firms investing in multiple financing stages seem either to fund a higher fraction of low quality companies or to give less management support compared to PE firms which invest in fewer financing stages. In comparison, neither diversification across industries nor countries have a significant effect on percentages of loss and percentage of total loss.

The remainder of the paper is organized as follows: in Section 2, a summary of related literature on the performance of PE investing is provided. Hypotheses on the impact of diversification on the performance of PE funds are developed in Section 3. Section 4 summarizes the data set, addresses selection biases, and describes the key variables. Descriptive statistics on the level of diversification and performance of PE funds is presented in Section 5. In Section 6 the impact of diversification on PE funds' performance is analyzed. In Section 7 additional robustness checks are described. Section 8 concludes the paper and discusses implications of the findings.

\section{Related literature on private equity}

Provoked by the boom of the PE industry in the late nineties, the number of articles on the return of PE investments has grown steadily due to the availability of larger data sets and an increasing interest in PE. Among these, two different groups of studies can be identified according to their unit of analysis. The first group of articles investigates the performance of single PE investments (Gompers \& Lerner 2000, Ljungqvist \& Richardson 2003b, Cumming \& Walz 2004, Cochrane 2005, Ick 2005). The second group's computations are based on PE funds (Ljungqvist \& 
Richardson 2003a, Jones \& Rhodes-Kropf 2003, Kaserer \& Diller 2004b, Gottschalg et al. 2004, Kaplan \& Schoar 2005) $\left.\right|^{2}$

Kaplan \& Schoar (2005) and Gottschalg et al. (2004) report a positive and concave relationship between fund size and rate of return of PE funds. The concave shape of the relationship suggests a decreasing return to scale of fund size. In addition, their results also suggest a positive impact of firm experience on the rate of return of $\mathrm{PE}$ funds. The more experience a $\mathrm{PE}$ firm has at the time of fund formation, the higher the rate of return of PE funds, ceteris paribus. Kaserer \& Diller (2004b) find a negative influence of the annual rate of return of the MSCI Europe Index in the vintage year of European PE funds on their rate of return. Next, an increasing amount of new funds raised by the PE industry in the vintage year of a PE fund is associated with a rise of its rate of return (Kaserer \& Diller 2004b, Gottschalg et al. 2004). Moreover, Gottschalg et al. (2004) report a negative influence of the fraction of the capital invested in Europe on the rate of return of a PE fund. In the past, European PE funds achieved a lower rate of return than their US counterparts. Finally, some authors report a superior return of venture capital (VC) funds over buyout (BO) funds (Kaplan \& Schoar 2005, Kaserer \& Diller 2004b), whereas other studies find no difference (Gottschalg et al. 2004) or a negative difference between VC funds and BO funds (Ljungqvist \& Richardson 2003a). In order to review and control for these effects I will include corresponding variables in my analysis $3^{3}$

Much less is known on the impact of diversification on the performance of PE funds so far. Ljungqvist \& Richardson (2003a) find no significant influences of diversification across the number of portfolio companies and industries on the internal rate of return (IRR) for their sample of mainly BO funds. Schmidt (2004)

2 A third group of articles studies the returns of publicly traded PE vehicles, which will not be further discussed in the scope of this article. For a recent study on publicly traded PE vehicles compare Zimmerman, Bilo, Christiophers \& Degosciu (2005).

3 Additionally, Kaplan \& Schoar (2005) and Kaserer \& Diller (2004b) find a performance persistence across funds of the one PE firm. PE firms who outperform the industry in one fund are likely to outperform the industry in the next fund. Unfortunately, the return of preceding fund is only available for 69 of the 100 sample funds. Hence, the return of preceding fund is not included in the regression analyses of this paper. In unreported regressions with only 69 $\mathrm{PE}$ funds I also find a positive and statistically significant persistence across funds of one PE firm. 
reports a decreasing variation of returns across simulated PE portfolios with a rising number of companies in the portfolio. Moreover, Weidig \& Mathonet (2004) show that the probability of loss and total loss of VC investments decline from direct investments in portfolio companies to VC funds, and from VC funds to simulated VC fund-of-funds.

The cited studies reveal interesting insights. Nevertheless, there is a lack of understanding about the impact of diversification on PE funds' performance. This paper contributes to this research gap by analyzing empirically the impact of diversification across number of portfolio companies, time, financing stages, industries, and countries on the rate of return and the percentage of loss of PE funds.

\section{Theoretical aspects and hypotheses}

The selection and oversight of private companies is characterized by serious information asymmetries and principal agent problems (Chan 1983, Amit et al. 1998). As a consequence, PE firms specialized in particular financing stages, industries, and countries should enjoy at least three advantages compared to non-specialized PE firms. First, before PE firms invest in a company they run a rigorous and multi-staged selection process (Tyebjee \& Bruno 1984, MacMillan, Zemann \& Subbanarasimha 1987, Birley, Muzyka \& Hay 1999). During this selection process the PE firm faces a substantial information asymmetry compared to the management team or vendor of the potential portfolio company. Specific knowledge in the technology and business of the potential investment assists the PE firm to reduce the information gap, and hence, to distinguish successful from unsuccessful investments.

Secondly, once a PE firm finances a company a principal agent problem exists between the PE firm (principal) and the management team of the portfolio company (agent). The personal benefits the management team gains from running the portfolio company might differ from the interests of the PE firm. Gompers (1995) names two likely examples of projects causing agency costs: the portfolio company might pursuit strategies or projects that have a high personal return for the management team but a low expected pay-off to shareholders, or the management 
team might invest in high variance strategies because their equity stakes are similar to call-options. PE firms use various instruments to reduce such agency conflicts. Among these are: the staging of capital infusions (Gompers 1995) and extensive control rights (Sahlman 1990, Kaplan \& Strömberg 2000). The more knowledge a PE firm has about the industry and markets of the portfolio company, the more effectively it is able to execute stage financing and control rights.

Thirdly, PE firms claim to add value to their investments by means of engagement in the managerial activities of the portfolio companies (Gorman \& Sahlman 1989, Hellmann \& Puri 2001, Hellmann \& Puri 2002). Again, the larger the know-how of the PE firm in the activities of the portfolio company is, the more value adding services the $\mathrm{PE}$ firms should be able to offer.

In summary, by means of specialization, $\mathrm{PE}$ firms should be able to make superior selection decisions and to provide their portfolio companies with more value adding services which in turn raises the rate of return of their portfolio companies. As a consequence, $\mathrm{PE}$ funds specialized in specific financing stages, industries, and countries should have higher rates of return and should lose less of their portfolio companies (Gupta \& Sapienza 1992, Norton \& Tenebaum 1993). The specialization hypothesis proposes a negative relationship between the level of diversification and the rate of return of PE funds. Accordingly, it suggests a positive relation between the level of diversification and the percentage of loss in a PE fund.

\section{Data and variables}

\subsection{Construction of data set}

The core data for this paper is derived from the records of a European PE fundof-funds investor. The data set was collected manually between April 2004 and October 2005. The information on PE firms, funds and its portfolio companies

were extracted from the due diligence documents provided by the PE firms to the investor.

The data contains detailed information on PE firms, their funds, and funds' portfolio companies. Concerning the PE firm, the year of firm foundation, the ge- 
ographic location of offices, and the funds managed since foundation is available. For each fund of a PE firm the following data was collected: the vintage year, the total amount committed, and the investment focus as specified by the PE firm. Additionally, for each fund a complete listing of all investments is available. For each portfolio company a set of descriptive variables was gathered. In particular, the date of initial investment by the PE fund, the industry of main activity, the geographic location of the headquarters, and the financing stage at the time of initial investment was stored. In the case an observation was unknown, the variables were completed through the following external resources. If in existence, the website of the portfolio company was scanned for additional information. Additionally, the website of the PE firm was screened for supplementary data. If both sources did not reveal the necessary information, the commercially available records of Thomson Venture Economics (TVE) were investigated. The information found in TVE was only adopted if other variables for the portfolio company coincided with the information in the due diligence documents. To measure the financial performance of the PE funds the exact cash flow records between the fund and its investors net of carried interests and the management fees were collected (in the following called the net cash flows). For the same purpose, the exact timing and size of cash flows between the fund and each portfolio company at the time of data collection were saved (in the following called gross cash flows). In total, information on $227 \mathrm{PE}$ funds of $51 \mathrm{PE}$ firms were collected.

In order to evaluate the performance of PE funds in this paper, I use a sample of mature PE funds, for which the entire gross cash flow history between portfolio companies and funds are available. Kaplan \& Schoar (2005) report a correlation of 0.89 between the final IRR and interim IRR after five years for a large sample of $\mathrm{PE}$ funds. Their result suggests that the interim performance of a mature PE fund is a valid proxy of final performance. The extent to which the interim performance can differ from the final performance depends on the amount of net asset value (NAV) at the time of the interim calculation. I define PE funds as mature and include them in the analysis which have a NAV of less than $20 \%$ relative to their 
total value.4 To conclude, the sample used in this paper contains information about 2,871 investments made by $100 \mathrm{PE}$ funds of $34 \mathrm{PE}$ firms.

Table 1 summarizes the composition of the sample. It can be divided into 38 VC and 62 BO funds 52 funds belong to PE firms with headquarters in the USA. The headquarters of the remaining 28 funds are located in Germany, France, Italy, Sweden, and the United Kingdom. The sample includes 21 first-time, 17 secondtime, and 14 third-time funds. The remaining 48 are PE funds with sequence numbers of four or higher. Forty funds were already liquidated at the time of data collection while the remaining 60 funds were still active. The active funds have an average fraction of NAV of $6.4 \%$ compared to total value .

The average fund sequence number of sample funds is 4.1. BO funds have higher sequence numbers than VC funds with means of 5.0 compared to 2.1, respectively. Also, US funds in the sample have higher sequence numbers than European funds (4.2 compared to 3.9). Finally, active funds show higher sequence numbers than liquidated funds (4.6 compared to 3.5).

Fund size varies substantially across funds. The mean size of the three smallest funds is USD 21.3 million, while the average size of the three largest funds totals up to USD 4,761 million. The average fund has a size of USD 440.2 million. VC funds have a smaller fund size than BO funds (USD 172.2 million compared to USD 604.4 million). Fund size increases significantly with sequence number. The mean fund size grows from USD 83.6 million for first-time funds to USD 759.2 million for funds, which have sequence numbers of four or higher. Equivalently, liquidated funds in the sample have a much smaller size than active funds (USD 286.8 million compared to USD 542.8 million). Finally, US funds are on average larger than European funds (USD 498.2 million compared to USD 291.0 million).

4 Kaserer \& Diller (2004b) include PE funds in their analysis if their NAV is less than $20 \%$ of the absolute value of all previously accrued cash flows. I follow this approach, however, with a small distinction: I use the total value of a PE fund as reference for the NAV. Total value is defined as the sum of realized proceeds and NAV.

5 A fund is categorized as VC if the fraction of its total capital invested in VC transactions is equal to or superior to $70 \%$. The remaining funds are classified as BO funds. Mezzanine funds and pre-fund vehicles are excluded from the analysis. 


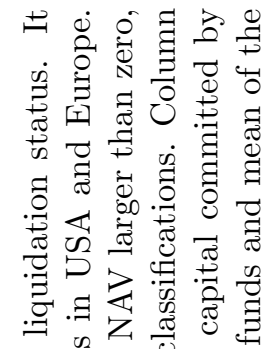

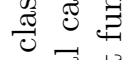

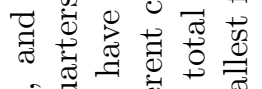

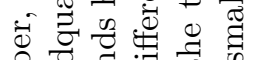

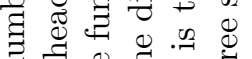

$\exists=$

啩突

उ $4 . \exists$

羊 घं

क द्वां

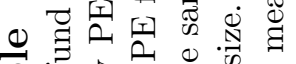

है

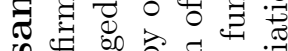

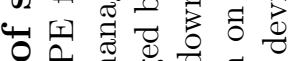

द

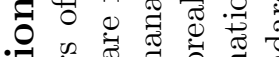

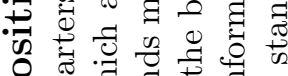

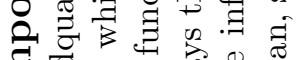

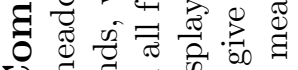

政

.

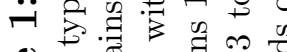

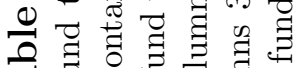

न

요웅

so శ్

० 0 :

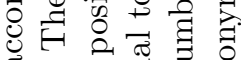

次 击

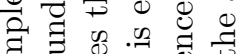

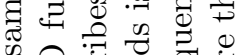

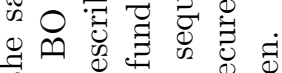

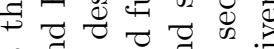

\%

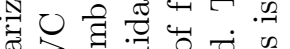

$\exists>\Xi$ 몀

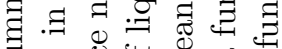

के एँ

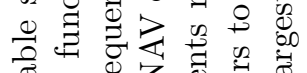

更 of

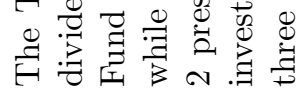

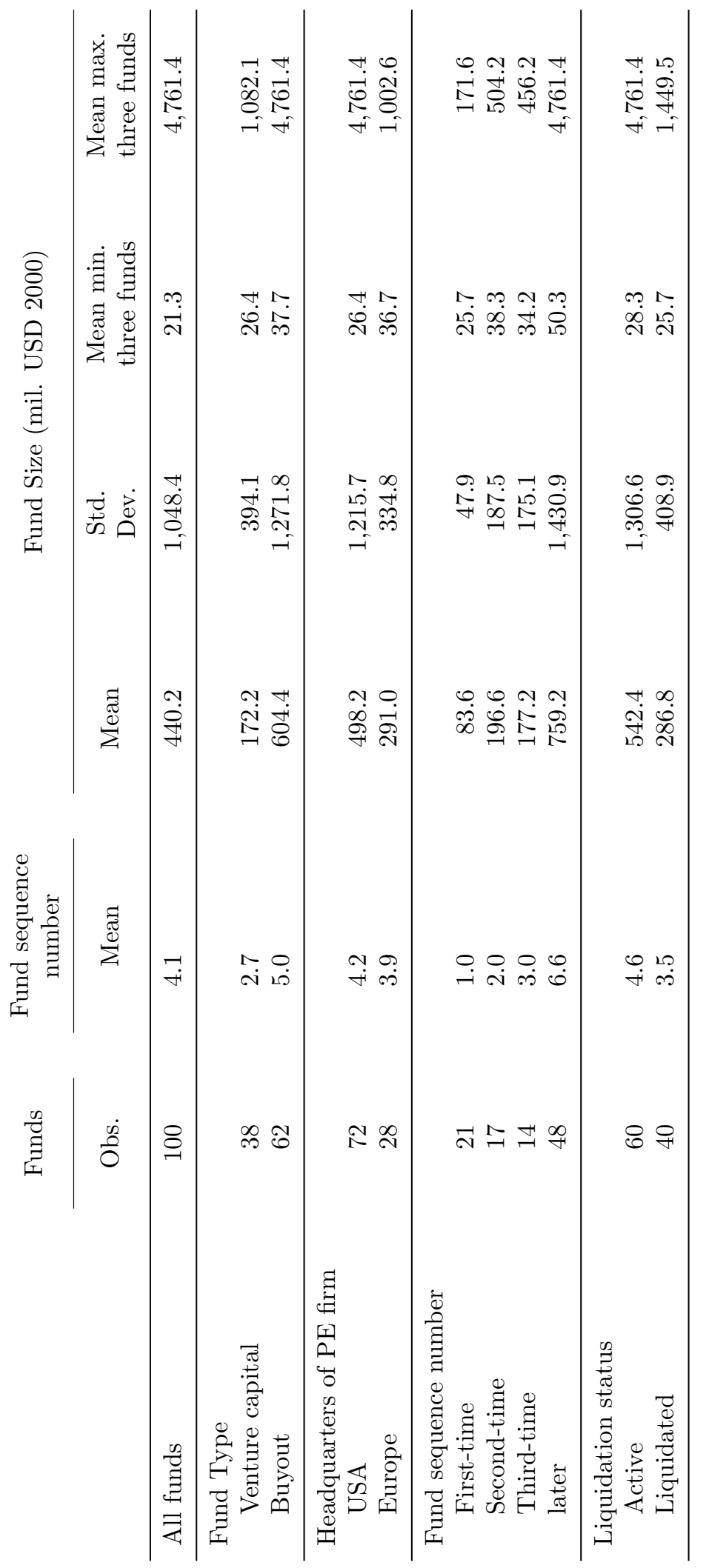


The oldest fund in the sample closed its first transaction in 1979; the youngest in 1998 6

Additional information is taken from commercially available data bases. The annual amount of new funds raised worldwide by the PE industry is taken from the statistics of TVE. The rate of return of the MSCI World Index twelve months prior to the first investment of a PE fund and exchange rates to convert the fund size of European PE funds to USD are obtained from Thomson Financial Datastream. The yearly consumer price index of the U.S. Department of Labor was used to express funds size and new funds raised in 2000 purchasing power.

\subsection{Discussion of selection bias}

The term 'private' is indicative of one of the main challenges for empirical research of the PE industry. Since there is no liquid secondary market for PE investments access to comprehensive data on $\mathrm{PE}$ transactions requires the collaboration of insiders. As a result, most data sets used to study the PE industry are restricted by size, level of detail, and/or selection biases.

The sample used in this paper has a unique level of detail but is not a random sample. It consists of all $\mathrm{VC}$ and $\mathrm{BO}$ funds, which belong to a $\mathrm{PE}$ firm that (1) undertook fundraising activities for a new fund between 2000 and August 2005 and (2) were asked by the fund-of-funds investor to provide due diligence documents. The time span of longer than five years is larger than the usual fund raising cycle of $\mathrm{PE}$ funds of three to four years. Hence, the sampling period is not expected to cause any bias. However, it implies survivorship bias. No funds are included in the sample that have a vintage year before 2000 and were managed by a PE firm, which did not try to raise a fund between 2000 and July 2005. This suggests that the funds of these PE firms started before 2000 generated a poor performance. Discussions with partners of the fund-of-fund-investor indicate that PE firms creating poor returns in two subsequent funds have a very low probability of raising a new fund. Consequently, the funds included in the sample can be considered a positive selection of the population in terms of return.

6 Figure 1 in the appendix displays the distribution of sample funds across vintage years. 
Additional selection biases could be caused by the investment preferences of the cooperation partner. Because of a regional focus, no funds of PE firms, which have their headquarters outside USA or Europe are included in the sample. This does not restrict the analysis critically, as USA and Europe are by far the biggest PE markets.7 Additionally, the cooperation partner only engages in due diligence activities for funds of PE firms it rates as 'high-quality-teams'. Some part of the rating stems from past performance of PE firms implying again a positive selection with reference to return.

A comparison of IRR net of management fee and carried interest (Net-IRR) corroborates the survivorship bias. Sample funds have on average a superior performance than the aggregated performance data provided by TVE. The median (average) Net-IRR for US PE funds with vintage years between 1979-1998 reported by TVE is $9.0 \%$ (18.3\%), while US funds in the sample have a median (average) Net-IRR of $28.5 \%$ (35.6\%). The corresponding values for European PE funds with vintage years between 1989-1998 are 5.5\% (11.4\%) and 26.3\% (29.8\%), respectively ${ }^{8}$ Most of the PE funds included in the sample belong to the 'top-half' performers within their peer group.

However, it is not expected that the relationship between diversification and performance in the sample differs significantly from the relationship between diversification and performance in the population of PE funds. First, although sample funds have a superior mean return, there is still a huge variation in the sample funds' returns. Secondly, there is also a huge variation in the levels of diversification across sample funds 9 Furthermore, in an additional robustness check I rerun the analysis excluding the upper quartile of the sample with respect to IRR in

7 The limitation to US and European based PE funds does not mean that no investments in companies outside USA and Europe are included in the data set. US and European PE firms also fund companies outside their home markets. The distribution of portfolio companies across countries is reported in panel $\mathrm{C}$ of Table 11 in the appendix.

8 Net-IRR was compuTable for 63 US and 27 European sample funds with vintage years between 1979-1998 and 1989-1998, respectively. TVE benchmark contains 1,138 US and 387 European PE funds with corresponding vintage years. The benchmark reports in TVE were generated April 17, 2006.

$9 \quad$ See descriptive analysis in section 5 . 
order to show that the results are not only driven by the top performing funds in the sample 10

Moreover, in an unreported probit regression I evaluate whether fund size, vintage year, the headquarters of the $\mathrm{PE}$ firm managing a fund, or the type of a fund have a significant influence on the probability of a PE fund to enter the sample compared to the average PE fund in the universe of PE funds in the sample period according to the statistics of TVE 11 I find that BO and larger funds are over-represented in the sample, while funds with higher vintage years are slightly under-represented. These biases are not problematic as fund size and vintage years are included as independent variables in the multivariate analyses presented.

\subsection{Description of variables}

\subsubsection{Measurement of performance}

As PE investments are only occasionally traded on secondary markets, return measurement usually relies on the cash flow history of a fund. The objective of this paper is to study whether specialized PE funds are able to make superior selection decisions and to add more value than diversified PE funds. It is not the aim to analyze whether specialized PE funds take higher management fees and carried interests or are able to time their distributions differently from diversified funds. As a consequence, in contrast to many prior studies, the performance of sample funds in this paper is measured on the gross cash flows between a PE fund and its portfolio companies, which are gross of management fees and carried interests.

I measure the rate of return of sample funds in terms of internal rate of return $(I R R)$, modified internal rate of return $(M I R R)$, and public market equivalent $(P M E) L^{12}$ All three consider the exact timing and size of all cash flows between a $\mathrm{PE}$ fund and its portfolio companies. IRR is the discount rate that yields a net

10 For detailed information see section 7.

11 Sample funds were identified in the universe of PE funds reported by TVE. All but two sample funds could be matched to the records of TVE. In sum the probit regression contains 4,024 PE funds.

12 For a more detailed discussion of the advantages and disadvantages of various return measures for PE funds see Kaserer \& Diller (2004a). 
present value of zero for the cash flow history of an investment. IRR implicitly assumes that interim cash flows are (re)invested at the same IRR. In most cases this reinvestment assumption is unrealistic. Neither PE firms nor investors are immediately able to reinvest in projects with the same IRR. MIRR reduces this problem by making an explicit assumption about the discount rate for interim cash flows (Dorsey 2000). Negative interim cash flows occurring during the investment's lifetime are discounted at a specific discount rate to period 0. Accordingly, positive interim cash flows are reinvested at a specific discount rate until the last cash flow has occurred. In this paper, I use a constant discount rate of $9 \%$, which is equal to the annual rate of return of the MSCI World Index during 1979 and 2005. PME compares the investment in a PE fund to the investment in a public market index (Kaplan \& Schoar 2003). It is defined as the ratio of the present value of all cash inflows to the fund (i.e., realizations of portfolio companies) over the present value of all cash outflows from the fund (i.e., investments in portfolio companies) using the public market index as discount rate (Kaserer \& Diller 2004b). As the sample contains European and US PE funds, I use the MSCI World Index as public market index. ${ }^{13}$

Finally, I include net asset value (NAV) in the calculation of IRR, MIRR, and PME. Gottschalg et al. (2004) document that the average ratio of present value of future cash flows to NAV in December of each year after the eighth birthday of a PE fund is 1.03. This implies that NAV in the last part of a funds' lifetime is a good proxy for future cash flows.

The specialization hypothesis also suggests that specialized PE funds show a lower percentages of loss than diversified PE funds. In this paper I use two different levels of loss: (1) percentage of loss (Perc(loss)) is estimated as the percentage of portfolio companies in a PE fund returning less than zero percent; (2) percentage of total loss (Perc(tot. loss)) is evaluated as the percentage of portfolio companies in a PE fund with a rate of return of $-100 \%$ (Dorsey 2000, Born 2004, Weidig \& Mathonet 2004).

13 Mathematical definitions for IRR, MIRR, and PME are displayed in Table 9 in the appendix. 


\subsubsection{Measurement of diversification}

PE firms are able to diversify their funds across five dimensions: (1) 'naive' diversification across the number of portfolio companies, (2) 'dynamic' diversification across time, (3) 'systematic' diversification across financing stages, (4) industries, and (5) countries.

The variable number of portfolio companies evaluates 'naive' diversification across a randomly selected portfolio of risky assets (Evans \& Archer 1968). It counts the number of portfolio companies $N$ in a PE fund.

Diversification across time reflects how fast a PE fund spends its capital. First, the start of a PE fund's investment activities is determined as the investment date of its first portfolio company. Secondly, for each portfolio company the time span between its date of investment and the date of investment of the first portfolio company, i.e., the start of the PE fund's investment activities is calculated. Thirdly, the time span is weighted with the fraction of the fund invested in portfolio company $i$. Finally, the value-weighted average for a fund is calculated.

I calculate Herfindahl-Hirschmann-Indices (HHI) to measure diversification across financing stages, industries, and countries in a PE fund. In order to do so, each portfolio company is assigned to one financing stage, industry, and country. Each HHI is computed by squaring the fraction of capital invested in the categories and then summing up the resulting numbers. Finally, for the purpose of easy interpretation I subtract the HHIs from one. Hence, HHI takes on the value of 0 for a fund, which is not diversified at all (i.e., a fund which invested only in one financing stage, industry, or country), and the value of 1 for a perfectly diversified fund (i.e., a fund which invested in an infinite number of financing stages, industries, or countries).

To measure diversification across financing stages I assigned each portfolio company to one financing stage. The following five categories were used: (1) seed and early stage VC, (2) second, expansion and later stage VC, (3) BO, (4) listed securities, and (5) other financing stages ${ }^{14}$ In most cases the categorization of the portfolio companies provided by the PE firms was identical to my classification

14 Definitions of the categories are described in Table 10 in the appendix. 
scheme, and thus, the categorization to the categories (1) to (5) was without difficulty. In cases where no direct correspondence existed, further search on the status of the company at the date of initial investment was conducted in external resources. Through this method more than $99 \%$ of the portfolio companies could be classified.

In order to calculate diversification across industries each portfolio company was assigned uniquely to the industry class of its major operations. First, I used the industry classification of TVE on its two-digit-level. The assignment was made upon the description of the portfolio companies given by the investing $\mathrm{PE}$ firm in the due diligence documents. To verify the classification, the results were compared with the record of TVE for each portfolio company. $95 \%$ of all portfolio companies could be classified 15 Secondly, to minimize the subjectivity associated with the classification, the two-digit-classification was aggregated to nine industry segments used by Gompers, Kovner, Lerner \& Scharfstein (2005): (1) Internet and Computers, (2) Communications and Electronics, (3) Business and Industrial, (4) Consumer, (5) Energy and Utilities, (6) Biotechnology and Healthcare, (7) Financial Services, (8) Business Services, and (9) Other. Gompers et al. claim that their classification scheme groups companies that have similarities in technology and markets. Therefore, it also qualifies for the evaluation of diversification across industries.

Finally to compute diversification across countries, each portfolio company was assigned to the country of its headquarters and a HHI across the fraction of capital invested in each country was computed. The geographic location of the headquarters was available for all portfolio companies. Table 11 in the appendix summarizes the distribution of portfolio companies across financing stages, industries, and countries.

\subsubsection{Measurement of additional variables}

I calculate the continuous return of the MSCI World Index the twelve months prior to the first investment of a PE fund (Return MSCI in vy) in order to measure the

15 The portfolio companies, which could not be classified to one of the financing stages or industries because of missing information, were not considered for the calculation of HHI. 
condition of the global economy during fundraising. The logarithm of new funds raised worldwide by $\mathrm{PE}$ firms in the vintage year of a $\mathrm{PE}$ fund (Funds raised in vy) represents the economic prospect of the PE industry at the time of fund formation ${ }^{16}$ Fund size is measured as the logarithm of total commitments of investors to a PE fund. To measure the experience of a PE firm at the time of fund formation (Firm experience), I take the logarithm of the vfund sequence number. I assume that the additional experience, which a PE firm gains in the management of an extra fund, decreases with fund sequence number.

Funds are classified to the location of their headquarters (European headquarters) and their stage focus ( $V C$ fund). I distinguish PE firms with headquarters in the USA and Europe. A fund is categorized as VC if the fraction of its total capital invested in $\mathrm{VC}$ transactions is equal to or superior to $70 \%$. The remaining funds are classified as PE funds. Finally, I include year fixed effects as control variables. Because of the limited sample size, I allocate funds to groups formed by subsequent three years. The groups are: 1977-1979, 1980-1982, 1983-1985, 1986-1988, 1989-1991, 1992-1994, 1995-1997, 1998-2000, and 2001-2003.

\section{Descriptive statistics}

Panel A of Table 2 summarizes the performance of sample funds. The average PE fund in the sample has an IRR of $50.2 \%$ and a MIRR of $19.9 \%$ gross of management fees and carried interests 17 The large difference between the average IRR and the average MIRR challenges the assumption of the IRR that interim cash flows are reinvested at same IRR. The reinvestment assumption of IRR artificially

16 The amount of new funds raised has been utilized in previous studies to proxy two different phenomena. On the one hand, the relative amount of capital flowing into one financing stage, industry, or country estimates the amount of money competing for the quantity of investment opportunities in the segment (Gompers \& Lerner 2000, Ljungqvist \& Richardson 2003a, Kaserer \& Diller 2004b). On the other hand, the total amount of capital raised by the PE industry in a year approximates the prospect of the PE industry through investors (Kaserer \& Diller 2004b, Gottschalg et al. 2004). I use the second approach in this paper.

17 The returns in this paper are measured gross of management fees and carried interest. As a result, they cannot be compared to the returns given in the articles of Ljungqvist \& Richardson (2003a), Jones \& Rhodes-Kropf (2003), Kaserer \& Diller (2004b), Gottschalg et al. (2004), and Kaplan \& Schoar (2005). The median and average net IRR of sample funds are given in the sample selection analysis (section 4.2 . 
enhances the spread between top and low performing PE funds. The minimum IRR and minimum MIRR are nearly equal with values of $3.5 \%$ and $6.7 \%$, respectively. In contrast, the maximum IRR and maximum MIRR differ by 130.3 percentage points. Hence, a big part of the high cross-sectional variance in the returns of PE funds reported by many previous studies may be explained by the inappropriate reinvestment assumption of the IRR. Still, there is a substantial variation across sample funds in terms of MIRR with a standard deviation of 7.2 percentage points and a spread between minimum and maximum MIRR of 38.7 percentage points. With a mean PME of 3.1 gross of management fees and carried interests the average fund in the sample returned three times more than the MSCI World Index. The minimum PME is 0.79 and the maximum PME is 11.9.

On average $34.9 \%$ of the portfolio companies in a sample fund returned less than their investment. Of these, $15.7 \%$ did not return anything at all. Percentages of loss vary remarkably across sample funds. The maxima are reached with $76.9 \%$ of losses and $42.9 \%$ of total losses in a single fund. In contrast, there are funds in the sample without any loss or total loss.

Panel B of Table 2 describes the level of diversification of PE funds in the sample. Very different levels of diversification can be observed across PE funds. Diversification across financing stages, industries, and countries varies substantially across sample funds with means of $0.36,0.64$, and 0.14 , and standard deviations of $0.22,0.18$, and 0.20 , respectively. The minimum level of diversification across financing stages, industries, and countries is 0 . Hence, the corresponding funds only invest in one financing stage, industry, or country. In contrast, the maximum level of diversification across financing stages is 0.68 , across industries 0.85 , and across countries 0.81 . This is equal to 4 financing stages, 9 industry segments, and 16 countries.

To further highlight the high variation of 'systematic' diversification across PE funds, the least diversified PE fund in the sample only invests in 1 financing stage, 3 industries, and 1 country, whereas the most diversified fund spreads its capital across 4 financing stages, 7 industry segments and 16 countries. 


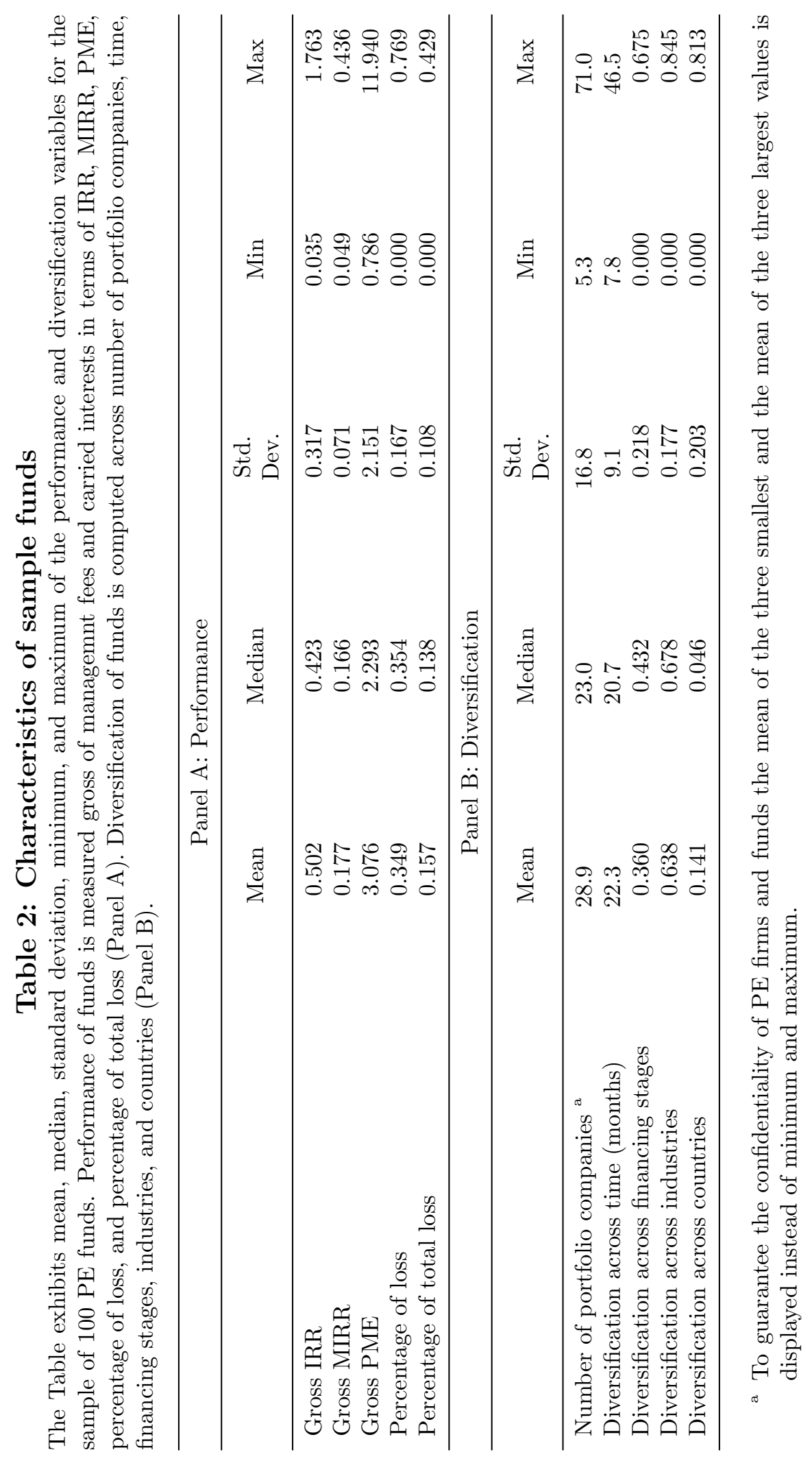


Accordingly, the number of portfolio companies and diversification across time vary significantly across sample funds. The average fund contains 28.9 portfolio companies and invest its capital in 22.3 months. The average of the three most numerous funds adds up to 71 portfolio companies, whereas the average of the three least numerous funds equals 5.3. The 'fastest' investing fund spends its capital in only 7.8 months, while the 'slowest' investing funds needs 46.5 months.

Table 3 shows the development of rates of return and percentages of loss over time. Because of the limited sample size, funds are arranged in groups of three vintage years. There is a time trend towards larger returns in the sample from a mean IRR of $26.2 \%$ in the period of $1980-1982$ to a mean IRR of $64.0 \%$ in 1995-1997. Neglecting the years of 1979 and 1998, only the period between 19861988 shows a decrease in mean IRR compared to the previous period. Looking at MIRR, the trend is even more apparent with a steady rise from a mean MIRR of $13.9 \%$ in 1980-1982 to a mean MIRR of $21.4 \%$ in 1992-1994. Only the period between 1995-1997 shows a MIRR which is slightly lower than in the previous period. However, the MIRR in 1995-1997 is still superior to all periods before 1992. This trend suggests that the development of the global PE market over the sample period enabled the PE firms to increase their returns. A similar pattern is reported by Kaplan \& Schoar (2005) 18 PME has a slightly different development. The mean PME first increases from 1.37 in 1980-1982 to a maximum of 3.90 in 1986-1988. Subsequently, it declines somewhat but stays at a high level above 3. The difference in the development of IRR and MIRR to PME can be explained by the influence of the MSCI World Index on the PME.

The percentages of loss depict a U-shaped pattern over the sample period. Percentages of loss and total loss fall from a level of $49.0 \%$ and $22.2 \%$ in 1979 to a minimum of $27.1 \%$ and $10.8 \%$ in $1989-1991$. Thereafter, they grow again to a level of $52.9 \%$ and $30.1 \%$ in 1998 .

18 Calculating average IRRs for the same three years groups, Table V of Kaplan \& Schoar (2005) also shows an increase in return from the period 1980-1982 to the period 1992-1994 with a small decline in the period 1986-1988 compared to the previous period. 
Table 3: Performance measures by vintage years

The Table displays the development of IRR, MIRR, PME, percentage of loss, and percentage of total loss gross of management fess and carried interests over the sample period from 1979 to 1998. Funds are arranged to groups of three vintage years.

\begin{tabular}{|c|c|c|c|c|c|c|}
\hline \multirow[b]{3}{*}{ Vintage year } & \multirow[b]{3}{*}{ Obs. } & \multicolumn{5}{|c|}{ Mean } \\
\hline & & \multicolumn{3}{|c|}{$\begin{array}{l}\text { Rate of } \\
\text { return }\end{array}$} & \multicolumn{2}{|c|}{$\begin{array}{l}\text { Percentage } \\
\text { of loss }\end{array}$} \\
\hline & & $\begin{array}{c}\text { Gross } \\
\text { IRR }\end{array}$ & $\begin{array}{l}\text { Gross } \\
\text { MIRR }\end{array}$ & $\begin{array}{l}\text { Gross } \\
\text { PME }\end{array}$ & $\mathrm{P}($ loss $)$ & $\begin{array}{c}\mathrm{P} \text { (tot. } \\
\text { loss })\end{array}$ \\
\hline All funds & 100 & 0.502 & 0.199 & 3.076 & 0.349 & 0.157 \\
\hline 1979 & 2 & 0.323 & 0.145 & 1.861 & 0.490 & 0.222 \\
\hline 1980-1982 & 4 & 0.262 & 0.139 & 1.366 & 0.374 & 0.216 \\
\hline 1983-1985 & 10 & 0.408 & 0.157 & 2.046 & 0.321 & 0.130 \\
\hline 1986-1988 & 8 & 0.391 & 0.184 & 3.899 & 0.282 & 0.109 \\
\hline 1989-1991 & 29 & 0.471 & 0.193 & 3.381 & 0.271 & 0.108 \\
\hline 1992-1994 & 21 & 0.596 & 0.234 & 3.584 & 0.379 & 0.175 \\
\hline 1995-1997 & 21 & 0.640 & 0.226 & 3.057 & 0.407 & 0.185 \\
\hline 1998 & 5 & 0.344 & 0.151 & 1.855 & 0.529 & 0.301 \\
\hline
\end{tabular}

\section{Diversification and performance of private eq- uity funds}

\subsection{Methodology}

The descriptive analysis gives a comprehensive overview of the data. This section aims at analyzing the impact of diversification on PE funds' performance in multivariate regressions. I regress performance measures on the five dimensions of diversification: number of portfolio companies, time, financing stages, industries, and countries. Additionally, the regressions include rate of return of the MSCI World Index in vintage year, new funds raised in vintage year, fund size, firm experience, and dummy variables indicating funds managed by PE firms with headquarters in Europe, VC funds, and year fixed effects, as well as a constant. I use OLS estimation methods. The linear model has the following form:

$$
y=\beta_{0}+\sum_{k=1}^{K} \beta_{k} \cdot x_{k}+\varepsilon
$$




$$
\begin{aligned}
\text { with } y & =\text { dependent variable } \\
\beta_{0} & =\text { constant } \\
\beta_{k} & =\text { parameter of independent variable } x_{k}, \\
x_{k} & =\text { independent variables, and } \\
\varepsilon & =\text { residual. }
\end{aligned}
$$

Standard errors are adjusted for serial correlation, heteroscedasticity and dependence between the observations of one PE firm (White 1980, Rogers 1993). The sample size of $100 \mathrm{PE}$ funds is limited. Hence, before I start with the regression analysis, a closer look is taken at the functional form of the dependent variables as well as on collinearity issues.

In line with previous articles, the distributions of IRR, MIRR, and PME appear to be right skewed (Figure 2). Cochrane (2001) and Jones \& Rhodes-Kropf (2003) suggest that the return of PE investments and funds can be represented best by means of a lognormal distribution. Consequently, some authors used a logarithmic transformation of returns as dependent variables in their analyses instead of the returns themselves (Hege, Palomino \& Schwienbacher 2003, Cumming \& Walz 2004, Gottschalg et al. 2004). I use the Box-Cox transformation in order to test whether logarithmic transformations of IRR, MIRR, and PME better fit the data than the variables themselves 19 The results of the Box-Cox estimations are presented in Table 12 in the appendix. For all variables the hypothesis that the data is best represented by a linear functional form is rejected at the $1 \%$ level. In contrast, for MIRR and PME the hypothesis that the data is best represented by a logarithmic transformation cannot be rejected at least at the $10 \%$ level. For IRR the hypothesis is rejected, but still at a lower level of significance than the hypothesis that the data follows a linear functional form. In summary, the tests favor a logarithmic transformation in two of three cases. Hence, I use the logarithm of IRR, MIRR, and PME as dependent variables rather than the variables themselves. To be consistent with previous studies I take the logarithm of $(1+\mathrm{IRR})$ and $(1+\mathrm{MIRR})$ so that $\log (1+\mathrm{IRR})$ and $\log (1+\mathrm{MIRR})$ equals zero when IRR and MIRR are zero (Cumming \& Walz 2004).

Another issue when working with small sample sizes is multi-collinearity. High collinearity between dependent variables lowers the precision of parameter estima-

19 For further details on Box-Cox transformation and its use see Box \& Cox (1964). 
tion. Neither product-moment correlations between the independent variables nor variance inflation factors (VIFs) (Neter, Wasserman \& Kutner 1990) show values which are expected to cause serious multi-collinearity issues without one exception. When year fixed effects are included in the regressions, there might be estimation difficulties of the variable new funds raised in vintage year in the corresponding regressions.

\subsection{The impact of diversification on private equity funds' rates of return}

The first question I address is whether diversification has a negative impact on the rate of return of a PE fund. The specialization hypothesis implies that specialized PE funds achieve higher rates of return than diversified PE funds. Therefore, I regress $\log (1+\mathrm{IRR}), \log (1+\mathrm{MIRR})$, and $\log (\mathrm{PME})$ on the five dimensions of diversification and the additional variables.

Tables 4, 5, and 6 summarize the regression results. They display the estimated parameters, robust standard errors, and summary statistics. For all three return variables I estimate three specifications, which vary among the dimensions of diversification. Specification (1) only includes 'naive' and 'dynamic' diversification. In contrast, specification (2) solely contains the three variables of 'systematic' diversification. In specification (3) I examine all five dimensions together. Moreover, I run a fourth regression, which incorporates year fixed effects as control variables. The F-tests on joint significance of all parameters are significant at the $1 \%$ level for all specifications. Moreover, the regressions explain between 19.7\% and $48.0 \%$ of the variance across sample funds' rates of return.

In all regressions the number of portfolio companies has a positive effect on the rate of return of $\mathrm{PE}$ funds. An increase in the number of portfolio companies from 25 to 35 increases IRR by 5.6 percentage points, MIRR by 1.6 percentage points, and PME by 0.35 , holding all other variables constant (Tables 4, 5, 6, columns (4)). The coefficient is statistically significant for all regressions except for column (3) of Table 4. Its direction and magnitude is sTable across all specifications. A possible explanation for the positive sign is the fact that holding fund size constant, a larger number of portfolio companies is equal to a lower average investment per 
portfolio company. Controlling also for fund types the lower average investment per portfolio company might be associated with lower prices paid for portfolio companies, explaining the positive effect.

According to the specialization hypothesis, the rate of return of a PE fund declines with diversification across financing stages. The effect is statistically significant at least at the $10 \%$ level when all dimensions of diversification and year fixed effects are included in the regressions. Moreover, it is negative in all regressions. The costs of diversification across financing stages appear to be quite high. An increase in diversification across financing stages by one standard deviation around its mean is connected with a decline of IRR by 6.5 percentage points, of MIRR by 1.9 percentage points, and of PME by 0.36, all else equal (Tables 4.5 . 6. columns (4)).

In contrast, the estimated coefficients for diversification across industries are positive in all regressions. For IRR and MIRR the relationship is statistically significant in specifications (2) at the $10 \%$ level when the number of portfolio companies and diversification across time is not included. For PME the coefficient is statistically significant in all specifications at the $5 \%$ level. A rise in diversification across industries by one standard deviation around its mean is linked to an increase of MIRR by 0.7 percentage points and of PME by 0.27 (Tables 4, 5, 6, columns (4)). This result is at odds with the specialization hypothesis which suggests that the rate of return of a $\mathrm{PE}$ fund declines with diversification across industries. In contrast, according to the data PE funds are able to diversify successfully across industries. The benefit of additional investment opportunities in new industries seems to be higher than the costs of diversification.

The estimated effects for diversification across time and countries are mostly insignificant and have different directions across the various regressions. Hence, the data suggests no systematic relationship of diversification across time and countries with the rate of return of PE funds. 
Table 4: OLS regression for $\log (1+$ IRR $)$

The sample consists of $100 \mathrm{PE}$ funds. The dependent variable is $\log (1+\mathrm{IRR})$. Independent variables include number of portfolio companies, diversification across time, diversification across financing stages, diversification across industries, diversification across countries, rate of return of the MSCI World Index in vintage year, new funds raised in vintage year, fund size, and firm experience. Additionally, the regressions contain dummy variables indicating funds managed by PE firms with headquarters in Europe and VC funds, as well as a constant. The Table reports estimated coefficients and robust standard errors.

\begin{tabular}{|c|c|c|c|c|}
\hline & \multicolumn{4}{|c|}{ Dependent variable: $\log (1+\mathrm{IRR})$} \\
\hline & (1) & $(2)$ & $(3)$ & $(4)$ \\
\hline Number of portfolio companies & $\begin{array}{c}0.002^{*} \\
(0.001)\end{array}$ & & $\begin{array}{c}0.003 \\
(0.002)\end{array}$ & $\begin{array}{l}0.004^{* *} \\
(0.002)\end{array}$ \\
\hline Div. across time (months) & $\begin{array}{l}-0.005^{*} \\
(0.003)\end{array}$ & & $\begin{array}{l}-0.005^{*} \\
(0.003)\end{array}$ & $\begin{array}{l}-0.005 \\
(0.004)\end{array}$ \\
\hline Div. across financing stages & & $\begin{array}{l}-0.085 \\
(0.099)\end{array}$ & $\begin{array}{l}-0.143 \\
(0.111)\end{array}$ & $\begin{array}{l}-0.202^{*} \\
(0.107)\end{array}$ \\
\hline Div. across industries & & $\begin{array}{c}0.185^{*} \\
(0.106)\end{array}$ & $\begin{array}{c}0.140 \\
(0.115)\end{array}$ & $\begin{array}{c}0.132 \\
(0.114)\end{array}$ \\
\hline Div. across. countries & & $\begin{array}{l}-0.002 \\
(0.074)\end{array}$ & $\begin{array}{l}-0.034 \\
(0.089)\end{array}$ & $\begin{array}{l}-0.112 \\
(0.109)\end{array}$ \\
\hline Return MSCI in vy & $\begin{array}{l}-0.490^{* * *} \\
(0.171)\end{array}$ & $\begin{array}{l}-0.408^{* * *} \\
(0.141)\end{array}$ & $\begin{array}{l}-0.516^{* * *} \\
(0.167)\end{array}$ & $\begin{array}{l}-0.451^{* *} \\
(0.175)\end{array}$ \\
\hline Funds raised in vy (log bil. USD 2000) & $\begin{array}{l}0.063^{* * *} \\
(0.020)\end{array}$ & $\begin{array}{l}0.078^{* * *} \\
(0.022)\end{array}$ & $\begin{array}{l}0.072^{* * *} \\
(0.020)\end{array}$ & $\begin{array}{c}0.044 \\
(0.065)\end{array}$ \\
\hline Fund size (log mil. USD 2000) & $\begin{array}{l}-0.064^{* * *} \\
(0.015)\end{array}$ & $\begin{array}{l}-0.054^{* * *} \\
(0.016)\end{array}$ & $\begin{array}{l}-0.073^{* * *} \\
(0.016)\end{array}$ & $\begin{array}{l}-0.063^{* * *} \\
(0.019)\end{array}$ \\
\hline Firm experience & $\begin{array}{c}0.035 \\
(0.022)\end{array}$ & $\begin{array}{c}0.020 \\
(0.024)\end{array}$ & $\begin{array}{c}0.027 \\
(0.023)\end{array}$ & $\begin{array}{c}0.012 \\
(0.025)\end{array}$ \\
\hline European headquarter $(0 / 1)$ & $\begin{array}{l}-0.077 \\
(0.050)\end{array}$ & $\begin{array}{l}-0.110^{*} \\
(0.061)\end{array}$ & $\begin{array}{l}-0.092 \\
(0.063)\end{array}$ & $\begin{array}{l}-0.077 \\
(0.069)\end{array}$ \\
\hline $\mathrm{VC}$ fund $(0 / 1)$ & $\begin{array}{l}-0.115^{* *} \\
(0.055)\end{array}$ & $\begin{array}{l}-0.084^{*} \\
(0.049)\end{array}$ & $\begin{array}{l}-0.128^{* *} \\
(0.056)\end{array}$ & $\begin{array}{l}-0.128^{*} \\
(0.065)\end{array}$ \\
\hline Constant & $\begin{array}{l}0.622^{* * *} \\
(0.159)\end{array}$ & $\begin{array}{c}0.390^{* *} \\
(0.151)\end{array}$ & $\begin{array}{l}0.615^{* * *} \\
(0.171)\end{array}$ & $\begin{array}{c}0.733^{* *} \\
(0.350)\end{array}$ \\
\hline Year F.E. & No & No & No & Yes \\
\hline F-statistic & 9.3 & 12.3 & 9.6 & 18.5 \\
\hline $\mathrm{p}$-value of $\mathrm{F}$-test & 0.000 & 0.000 & 0.000 & 0.000 \\
\hline$R^{2}$ & 0.197 & 0.184 & 0.227 & 0.309 \\
\hline$R^{2}$-adjusted & 0.126 & 0.103 & 0.131 & 0.155 \\
\hline Number of observations & 100 & 100 & 100 & 100 \\
\hline
\end{tabular}

Standard errors are in parentheses and are adjusted for serial correlation, heteroscedasticity and dependence between observations of one PE firm.

${ }^{*}$ significant at $10 \% ;{ }^{* * *}$ significant at $5 \%$; ${ }^{* *}$ significant at $1 \%$ 
Table 5: OLS regression for $\log (1+\mathrm{MIRR})$

The sample consists of $100 \mathrm{PE}$ funds. The dependent variable is $\log (1+\mathrm{MIRR})$. Independent variables include number of portfolio companies, diversification across time, diversification across financing stages, diversification across industries, diversification across countries, rate of return of the MSCI World Index in vintage year, new funds raised in vintage year, fund size, and firm experience. Additionally, the regressions contain dummy variables indicating funds managed by PE firms with headquarters in Europe and VC funds, as well as a constant. The Table reports estimated coefficients and robust standard errors.

\begin{tabular}{|c|c|c|c|c|}
\hline & \multicolumn{4}{|c|}{ Dependent variable: $\log (1+$ MIRR $)$} \\
\hline & (1) & $(2)$ & $(3)$ & $(4)$ \\
\hline Number of portfolio companies & $\begin{array}{c}0.001^{* *} \\
(0.000)\end{array}$ & & $\begin{array}{c}0.001^{*} \\
(0.000)\end{array}$ & $\begin{array}{l}0.001^{* *} \\
(0.001)\end{array}$ \\
\hline Div. across time (months) & $\begin{array}{l}-0.001 \\
(0.001)\end{array}$ & & $\begin{array}{l}-0.001 \\
(0.001)\end{array}$ & $\begin{array}{l}-0.001 \\
(0.001)\end{array}$ \\
\hline Div. across financing stages & & $\begin{array}{l}-0.030 \\
(0.029)\end{array}$ & $\begin{array}{l}-0.050 \\
(0.030)\end{array}$ & $\begin{array}{l}-0.071^{* *} \\
(0.029)\end{array}$ \\
\hline Div. across industries & & $\begin{array}{c}0.053^{*} \\
(0.027)\end{array}$ & $\begin{array}{c}0.033 \\
(0.030)\end{array}$ & $\begin{array}{c}0.034 \\
(0.029)\end{array}$ \\
\hline Div. across. countries & & $\begin{array}{c}0.036 \\
(0.025)\end{array}$ & $\begin{array}{c}0.020 \\
(0.024)\end{array}$ & $\begin{array}{l}-0.011 \\
(0.027)\end{array}$ \\
\hline Return MSCI in vy & $\begin{array}{l}-0.135^{* * *} \\
(0.047)\end{array}$ & $\begin{array}{l}-0.101^{* *} \\
(0.039)\end{array}$ & $\begin{array}{l}-0.133^{* * *} \\
(0.047)\end{array}$ & $\begin{array}{l}-0.107^{* *} \\
(0.043)\end{array}$ \\
\hline Funds raised in vy (log bil. USD 2000) & $\begin{array}{l}0.023^{* * *} \\
(0.005)\end{array}$ & $\begin{array}{l}0.025^{* * *} \\
(0.005)\end{array}$ & $\begin{array}{l}0.024^{* * *} \\
(0.005)\end{array}$ & $\begin{array}{c}0.015 \\
(0.018)\end{array}$ \\
\hline Fund size (log mil. USD 2000) & $\begin{array}{l}-0.018^{* * *} \\
(0.004)\end{array}$ & $\begin{array}{l}-0.018^{* * *} \\
(0.005)\end{array}$ & $\begin{array}{l}-0.023^{* * *} \\
(0.005)\end{array}$ & $\begin{array}{l}-0.020^{* * *} \\
(0.005)\end{array}$ \\
\hline Firm experience & $\begin{array}{c}0.014^{* *} \\
(0.006)\end{array}$ & $\begin{array}{r}0.013^{*} \\
(0.007)\end{array}$ & $\begin{array}{c}0.014^{* *} \\
(0.006)\end{array}$ & $\begin{array}{c}0.008 \\
(0.007)\end{array}$ \\
\hline European headquarter $(0 / 1)$ & $\begin{array}{l}-0.035^{* * *} \\
(0.010)\end{array}$ & $\begin{array}{l}-0.053^{* * *} \\
(0.013)\end{array}$ & $\begin{array}{l}-0.045^{* * *} \\
(0.012)\end{array}$ & $\begin{array}{l}-0.040^{* * *} \\
(0.014)\end{array}$ \\
\hline $\mathrm{VC}$ fund $(0 / 1)$ & $\begin{array}{l}-0.032^{* * *} \\
(0.011)\end{array}$ & $\begin{array}{l}-0.024^{* *} \\
(0.009)\end{array}$ & $\begin{array}{l}-0.037^{* * *} \\
(0.011)\end{array}$ & $\begin{array}{l}-0.039^{* *} \\
(0.015)\end{array}$ \\
\hline Constant & $\begin{array}{l}0.214^{* * *} \\
(0.037)\end{array}$ & $\begin{array}{l}0.179^{* * *} \\
(0.041)\end{array}$ & $\begin{array}{l}0.231^{* * *} \\
(0.046)\end{array}$ & $\begin{array}{l}0.268^{* * *} \\
(0.096)\end{array}$ \\
\hline Year F.E. & No & No & No & Yes \\
\hline F-statistic & 9.6 & 8.5 & 11.2 & 20.9 \\
\hline p-value of F-test & 0.000 & 0.000 & 0.000 & 0.000 \\
\hline$R^{2}$ & 0.250 & 0.249 & 0.284 & 0.407 \\
\hline$R^{2}$-adjusted & 0.184 & 0.174 & 0.195 & 0.275 \\
\hline Number of observations & 100 & 100 & 100 & 100 \\
\hline
\end{tabular}

Standard errors are in parentheses and are adjusted for serial correlation, heteroscedasticity and dependence between observations of one PE firm.

${ }^{*}$ significant at $10 \% ;{ }^{* * *}$ significant at $5 \%$; ${ }^{* *}$ significant at $1 \%$ 


\section{Table 6: OLS regression for $\log (\mathrm{PME})$}

The sample consists of $100 \mathrm{PE}$ funds. The dependent variable is $\log (\mathrm{PME})$. Independent variables include number of portfolio companies, diversification across time, diversification across financing stages, diversification across industries, diversification across countries, rate of return of the MSCI World Index in vintage year, new funds raised in vintage year, fund size, and firm experience. Additionally, the regressions contain dummy variables indicating funds managed by PE firms with headquarters in Europe and VC funds, as well as a constant. The Table reports estimated coefficients and robust standard errors.

\begin{tabular}{lcccc}
\hline & \multicolumn{3}{c}{ Dependent variable: $\log (\mathrm{PME})$} \\
\cline { 2 - 5 } & $(1)$ & $(2)$ & $(3)$ & $(4)$ \\
\hline Number of portfolio companies & $0.010^{* * *}$ & & $0.011^{* * *}$ & $0.013^{* * *}$ \\
& $(0.002)$ & & $(0.004)$ & $(0.005)$ \\
Div. across time (months) & 0.006 & & 0.004 & -0.003 \\
& $(0.006)$ & & $(0.006)$ & $(0.009)$ \\
Div. across financing stages & & -0.302 & $-0.566^{* *}$ & $-0.633^{* *}$ \\
& & $(0.241)$ & $(0.247)$ & $(0.235)$ \\
Div. across industries & & $0.962^{* * *}$ & $0.583^{* *}$ & $0.582^{* *}$ \\
Div. across. countries & & $(0.299)$ & $(0.270)$ & $(0.284)$ \\
& & $0.404^{*}$ & 0.058 & -0.124 \\
Return MSCI in vy & $(0.212)$ & $(0.210)$ & $(0.253)$ \\
& $-1.331^{* * *}$ & $-1.152^{* *}$ & $-1.362^{* * *}$ & $-1.215^{* * *}$ \\
Funds raised in vy (log bil. USD 2000) & $(0.440)$ & $(0.459)$ & $(0.440)$ & $(0.407)$ \\
& $0.188^{* * *}$ & $0.196^{* * *}$ & $0.219^{* * *}$ & 0.075 \\
Fund size (log mil. USD 2000) & $(0.048)$ & $(0.056)$ & $(0.044)$ & $(0.161)$ \\
Firm experience & $-0.161^{* * *}$ & $-0.214^{* * *}$ & $-0.204^{* * *}$ & $-0.196^{* * *}$ \\
& $(0.040)$ & $(0.052)$ & $(0.036)$ & $(0.043)$ \\
European headquarter (0/1) & $0.112^{*}$ & 0.143 & 0.087 & 0.067 \\
VC fund (0/1) & $(0.064)$ & $(0.088)$ & $(0.061)$ & $(0.062)$ \\
& $-0.376^{* * *}$ & $-0.647^{* * *}$ & $-0.484^{* * *}$ & $-0.492^{* * *}$ \\
Constant & $(0.102)$ & $(0.117)$ & $(0.120)$ & $(0.130)$ \\
& $-0.416^{* * *}$ & $-0.395^{* * *}$ & $-0.471^{* * *}$ & $-0.488^{* * *}$ \\
Year F.E. & $(0.108)$ & $(0.093)$ & $(0.106)$ & $(0.124)$ \\
\hline F-statistic & $0.980^{* *}$ & $1.101^{* *}$ & $0.998^{* *}$ & $1.705^{*}$ \\
p-value of F-test $R^{2}$ & $(0.397)$ & $(0.423)$ & $(0.408)$ & $(0.858)$ \\
$R^{2}$-adjusted & No & No & No & Yes \\
Number of observations & 17.5 & 8.7 & 34.6 & 31.0 \\
\hline Standard erors and & 0.000 & 0.000 & 0.000 & 0.000 \\
& 0.346 & 0.339 & 0.402 & 0.480 \\
& 0.289 & 0.273 & 0.327 & 0.364 \\
& 100 & 100 & 100 & 100 \\
\hline
\end{tabular}

Standard errors are in parentheses and are adjusted for serial correlation, heteroscedasticity and dependence between observations of one PE firm.

* significant at $10 \% ;{ }^{* * *}$ significant at $5 \% ;{ }^{* * *}$ significant at $1 \%$ 
The regressions further display interesting results in comparison with previous studies on the performance of PE funds. Consistent with Kaserer \& Diller (2004b), I find a strong negative link between rate of return of the MSCI World Index in vintage year and rate of return of a $\mathrm{PE}$ fund which is statistically significant at least at the $5 \%$ level in all regressions. A well performing global economy at the time of fund formation forces PE firms to pay high prices for their investments lowering the rate of return of their funds, all else equal. Varying the rate of return of the MSCI World Index in vintage year by one standard deviation from $4.7 \%$ to $14.7 \%$ leads to a decline of IRR of 6.6 percentage points, MIRR of 1.3 percentage points, and PME of 0.31, holding all other variables constant (Tables 4, 5, 6, columns (4)).

The data also supports the positive relationship between the amount of new funds raised by the global PE industry in the vintage year of a fund and its rate of return. Raising the logarithm of new funds raised in the vintage year by one standard deviation across its mean, increases IRR by 5.1 percentage points, MIRR by 0.7 percentage points, and PME by 0.15 , holding all other variables constant (Tables 4, 5, 6, columns (3)). This result backs the argumentation that the total amount of new funds raised by the PE industry in a year is a signal for future investment opportunities (Kaserer \& Diller 2004b, Gottschalg et al. 2004). As expected by the multi-collinearity analysis, the coefficient of new funds raised in vintage year loses its significance when year fixed effects are included. The amount of new funds raised has grown nearly constantly over the sample period according to the statistics of TVE. Only in the years 1990 and 1991, TVE quotes a decline of new funds raised compared to the previous year.

Consistent with Kaplan \& Schoar (2005) and Gottschalg et al. (2004), the relationship between the experience of a PE firm at the time of fund formation and the rate of return is positive for all specifications. Yet it is only statistically significant at the $10 \%$ level for MIRR when year fixed effects are not included 20

20 Kaplan \& Schoar (2005) report that for their sample the positive correlation between firm experience and funds' rates of return is only valid in cross section. Controlling for firm fixed effects they find a negative relationship between both variables. This suggests that the positive relation between firm experience and funds' rates of return in cross section is mainly caused by selection. Successful PE firms are able to raise follow-on funds, whereas 
Furthermore, I find a return difference between European and US PE funds, which is statistically significant at the $1 \%$ level for MIRR and PME, corroborating the result of Gottschalg et al. (2004). Over the sample period US PE funds achieved on average 4.8 percentage points higher MIRR and a 1.15 higher PME than their European equivalents, all else equal (Tables 5, 6, columns (4)).

However, contrary to the findings of Kaplan \& Schoar (2005) and Gottschalg et al. (2004), I find returns to decrease linearly with the logarithm of total commitments. A growth in fund size by one standard deviation around its mean lowers IRR by 11.4 percentage points, MIRR by 2.9 percentage points, and PME by 0.62 , holding all other variables constant (Tables 4, 5, 6, columns (4)) ${ }^{21}$ There are two possible explanations for this result. On the one hand, if one has a closer look at the results reported by Kaplan \& Schoar (2005), the IRR maximizing fund size for their sample is USD 90 million in 1990 purchasing power ${ }^{22}$ The returns of funds larger than the optimal value decline with fund size because the number of attractive companies in the economy is limited at each point in time (Kaplan \& Schoar 2005). In comparison, 56 funds in the sample have a fund size above USD 90 million in 1990 purchasing power. The three largest funds even have an average fund size of USD 3,618 million in 1990 purchasing power. Hence, the majority of sample funds lie far above the optimal fund size of Kaplan \& Schoar (2005) which might cause the negative sign in the regressions. On the other hand, controlling for the portfolio strategy of a PE fund may induce the sign change. For instance, holding number of portfolio companies constant, a larger fund size is associated with a larger average investment per portfolio company. Simultaneously controlling for fund type, the larger average investment per portfolio company might be equal to higher prices paid for portfolio companies, which would also explain the negative effect of fund size.

unsuccessful PE firms are not. Because of the limited size of the sample, I am not able to approve this hypothesis.

21 The inclusion of a quadratic term of fund size in an unreported regression does not change the direction of the effect.

${ }^{22}$ Kaplan \& Schoar (2005) report in Table VIII, column two, a coefficient of $\log$ (size) of 0.18 and of $\log (\text { size })^{2}$ of -0.02 . They measure fund size in USD million in 1990 purchasing power. 
Finally, VC funds in the sample return less than BO funds. The difference between both groups totals up to 18.6 percentage points in IRR, 4.6 percentage points in MIRR, and 1.20 in PME, all else equal (Tables 4, 5, 6, columns (4)). This result is at odds with Kaplan \& Schoar (2005) and Kaserer \& Diller (2004b) and might be explained by the superior return of sample funds ${ }^{23}$ Whereas $\mathrm{VC}$ funds achieve higher rates of return than $\mathrm{BO}$ funds in the universe of $\mathrm{PE}$ funds, comparing the rate of return of both groups only for the 'top-half' of PE funds, $\mathrm{BO}$ funds perform better than $\mathrm{VC}$ funds. An alternative explanation is that the quality of $\mathrm{BO}$ firms to which the fund-of-funds investor had access is superior to the quality of $\mathrm{VC}$ firms.

\subsection{The impact of diversification on private equity funds' percentages of loss}

The specialization hypothesis suggests that by means of specialization, PE firms are able to make superior selection decisions and to provide their portfolio companies with more value adding services. Consequently, specialized PE funds should lose fewer of there portfolio companies. In the following I test this hypothesis regressing percentage of loss, i.e., the fraction of portfolio companies with a return of less than $0 \%$, and percentage of total loss, i.e., the fraction of portfolio companies with a rate of return of $-100 \%$, on the five dimensions of diversification.

Table 7 and 8 display the results of OLS estimation of percentage of loss and probability of total loss ${ }^{24}$ For both measures I again estimate three specifications varying across the dimensions of diversification. Specification (1) restrains the analysis to number of portfolio companies and diversification across time, while specification (2) includes the three dimensions of 'systematic' diversification, which are: diversification across financing stages, industries, and countries. In specification (3) all five variables of diversification are examined together. Additionally, I estimate a fourth specification which includes year fixed effects as control variables.

23 Compare sample selection analysis in section 4.2

24 There are four funds in the sample which have a percentage of loss of zero and nine funds which have a percentage of total loss. As a consequence a Tobit model with left-censoring at zero would be more accurate. However, due to the small number of censored observations, the estimated coefficients are marginally different from the OLS estimations. 
The F-tests on joint significance of all parameters are significant at the $1 \%$ level for all specifications. Specification (4) explains $55.0 \%$ of the variation of percentage of loss and $40.5 \%$ of the variation of percentage of total loss across sample funds.

In line with the specialization hypothesis, diversification across financing stages enhances percentages of loss and total loss. The effects are statistically significant at least at the $5 \%$ level and sTable in magnitude across all specifications. A standard deviation change in diversification across financing stages raises the fraction of losses in a PE fund by 4.8 percentage points and the fraction of total losses by 3.1 percentage points, holding all other variables constant (Tables 7 and 8 , columns (4)). PE firms investing in multiple financing stages seem either to fund a higher fraction of low quality companies or to give less management support compared to PE firms which invest in fewer financing stages.

According to the rate of return, the coefficient for diversification across industries is negative in all specification for both percentages of loss. PE funds which are diversified across a broad range of industries appear to lose less of their portfolio companies than PE funds focused on certain industries. However, the effects are not statistically significant.

Diversification across countries does not seem to have a systematic effect on percentage of loss and total loss. The coefficients of diversification across countries are statistically insignificant and change signs across the various specifications.

Additionally, an increasing number of portfolio companies seems to be associated with a rise in percentage of loss and diversification across time appears to lower the percentage of loss in a PE fund, returning less than their investment. However, the coefficients of both variables become insignificant when year fixed effects are introduced.

Moreover, a growing amount of new funds raised in the vintage year of a PE fund enhances the percentages of loss. A doubling in the amount of new funds raised is associated with a 10.5 percentage points higher fraction of losses and a 5.7 percentage points higher fraction of total losses in a PE fund, all else equal (Tables 7 and 8, columns (4)). PE firms fund a disproportionately high fraction of low quality investments when a large amount of capital is available. 


\section{Table 7: OLS regression for percentage of loss}

The sample consists of $100 \mathrm{PE}$ funds. The dependent variable is percentage of loss, i.e., the fraction of portfolio companies in a $\mathrm{PE}$ fund returning less than $0 \%$. Independent variables include number of portfolio companies, diversification across time, diversification across financing stages, diversification across industries, diversification across countries, rate of return of the MSCI World Index in vintage year, new funds raised in vintage year, fund size, and firm experience. Additionally, the regressions contain dummy variables indicating funds managed by PE firms with headquarters in Europe and VC funds, as well as a constant. The Table reports estimated coefficients and robust standard errors.

\begin{tabular}{|c|c|c|c|c|}
\hline & \multicolumn{4}{|c|}{ Dependent variable: probability of loss } \\
\hline & $(1)$ & $(2)$ & $(3)$ & (4) \\
\hline \multirow[t]{2}{*}{ Number of portfolio companies } & $0.003^{* *}$ & & 0.002 & 0.002 \\
\hline & $(0.001)$ & & $(0.001)$ & $(0.001)$ \\
\hline \multirow{2}{*}{ Div. across time (months) } & $-0.005^{*}$ & & $-0.004^{*}$ & -0.002 \\
\hline & $(0.002)$ & & $(0.002)$ & $(0.003)$ \\
\hline \multirow{2}{*}{ Div. across financing stages } & & $0.297^{* * *}$ & $0.248^{* * *}$ & $0.224^{* * *}$ \\
\hline & & $(0.069)$ & $(0.075)$ & $(0.078)$ \\
\hline \multirow{2}{*}{ Div. across industries } & & -0.093 & -0.133 & -0.121 \\
\hline & & $(0.111)$ & $(0.094)$ & $(0.098)$ \\
\hline \multirow{2}{*}{ Div. across. countries } & & 0.029 & 0.000 & 0.020 \\
\hline & & $(0.080)$ & $(0.083)$ & $(0.085)$ \\
\hline \multirow{2}{*}{ Return MSCI in vy } & 0.000 & 0.111 & 0.022 & 0.024 \\
\hline & $(0.140)$ & $(0.131)$ & $(0.140)$ & $(0.138)$ \\
\hline \multirow{2}{*}{ Funds raised in vy (log bil. USD 2000) } & $0.055^{* *}$ & $0.052^{* * *}$ & $0.048^{* * *}$ & $0.105^{* *}$ \\
\hline & $(0.022)$ & $(0.018)$ & $(0.016)$ & $(0.041)$ \\
\hline \multirow{2}{*}{ Fund size (log mil. USD 2000) } & -0.015 & 0.016 & 0.001 & -0.002 \\
\hline & $(0.017)$ & $(0.015)$ & $(0.017)$ & $(0.020)$ \\
\hline \multirow[t]{2}{*}{ Firm experience } & 0.006 & 0.007 & 0.012 & 0.017 \\
\hline & $(0.029)$ & $(0.025)$ & $(0.026)$ & $(0.030)$ \\
\hline \multirow{2}{*}{ European headquarter $(0 / 1)$} & -0.002 & 0.004 & 0.020 & 0.016 \\
\hline & $(0.038)$ & $(0.040)$ & $(0.041)$ & $(0.044)$ \\
\hline \multirow[t]{2}{*}{$\mathrm{VC}$ fund $(0 / 1)$} & $0.124^{* *}$ & $0.184^{* * *}$ & $0.148^{* * *}$ & $0.135^{* *}$ \\
\hline & $(0.053)$ & $(0.043)$ & $(0.048)$ & $(0.050)$ \\
\hline \multirow{2}{*}{ Constant } & 0.193 & -0.055 & 0.122 & -0.141 \\
\hline & $(0.169)$ & $(0.126)$ & $(0.165)$ & $(0.223)$ \\
\hline Year F.E. & No & No & No & Yes \\
\hline F-statistic & 18.2 & 12.3 & 16.3 & 11.5 \\
\hline $\mathrm{p}$-value of F-test & 0.000 & 0.000 & 0.000 & 0.000 \\
\hline$R^{2}$ & 0.418 & 0.471 & 0.509 & 0.550 \\
\hline$R^{2}$-adjusted & 0.367 & 0.418 & 0.447 & 0.450 \\
\hline Number of observations & 100 & 100 & 100 & 100 \\
\hline
\end{tabular}

Standard errors are in parentheses and are adjusted for serial correlation, heteroscedasticity and dependence between observations of one PE firm.

${ }^{*}$ significant at $10 \% ;{ }^{* * *}$ significant at $5 \%$; ${ }^{* * *}$ significant at $1 \%$ 
Table 8: OLS regression for percentage of total loss

The sample consists of $100 \mathrm{PE}$ funds. The dependent variable is percentage of total loss, i.e., the fraction of portfolio companies in a PE fund returning nothing. Independent variables include number of portfolio companies, diversification across time, diversification across financing stages, diversification across industries, diversification across countries, rate of return of the MSCI World Index in vintage year, new funds raised in vintage year, fund size, and firm experience. Additionally, the regressions contain dummy variables indicating funds managed by PE firms with headquarters in Europe and VC funds, as well as a constant. The Table reports estimated coefficients and robust standard errors.

\begin{tabular}{lcccc}
\hline & \multicolumn{3}{c}{ Dependent variable: prob. of total loss } \\
\cline { 2 - 5 } & $(1)$ & $(2)$ & $(3)$ & $(4)$ \\
\hline Number of portfolio companies & 0.000 & & -0.001 & -0.001 \\
& $(0.001)$ & & $(0.001)$ & $(0.001)$ \\
Div. across time (months) & -0.002 & & -0.002 & 0.000 \\
& $(0.002)$ & & $(0.002)$ & $(0.002)$ \\
Div. across financing stages & & $0.140^{* * *}$ & $0.155^{* * *}$ & $0.144^{* *}$ \\
& & $(0.041)$ & $(0.047)$ & $(0.054)$ \\
Div. across industries & & -0.078 & -0.049 & -0.032 \\
Div. across. countries & & $(0.097)$ & $(0.088)$ & $(0.090)$ \\
& & -0.016 & 0.012 & 0.033 \\
Return MSCI in vy & & $(0.054)$ & $(0.066)$ & $(0.066)$ \\
& 0.019 & 0.039 & 0.037 & 0.044 \\
Funds raised in vy (log bil. USD 2000) & $(0.113)$ & $(0.120)$ & $(0.121)$ & $(0.130)$ \\
& $0.034^{*}$ & $0.035^{* *}$ & $0.032^{* *}$ & $0.057^{*}$ \\
Fund size (log mil. USD 2000) & $(0.018)$ & $(0.015)$ & $(0.015)$ & $(0.032)$ \\
Firm experience & -0.004 & 0.011 & 0.006 & 0.002 \\
& $(0.012)$ & $(0.012)$ & $(0.012)$ & $(0.012)$ \\
European headquarter (0/1) & 0.001 & -0.005 & 0.003 & 0.004 \\
VC fund (0/1) & $(0.021)$ & $(0.020)$ & $(0.018)$ & $(0.019)$ \\
Constant & -0.033 & -0.015 & -0.028 & -0.038 \\
& $(0.025)$ & $(0.023)$ & $(0.024)$ & $(0.026)$ \\
Year F.E. & 0.064 & $0.081^{* *}$ & $0.079^{* *}$ & $0.065^{*}$ \\
\hline F-statistic & $(0.040)$ & $(0.032)$ & $(0.035)$ & $(0.033)$ \\
p-value of F-test & 0.075 & -0.044 & 0.015 & -0.106 \\
$R^{2}$-adjusted & $(0.117)$ & $(0.110)$ & $(0.123)$ & $(0.155)$ \\
Number of observations & No & No & No & Yes \\
\hline Standard & 4.7 & 7.4 & 6.6 & 16.8 \\
& 0.000 & 0.000 & 0.000 & 0.000 \\
& 0.244 & 0.300 & 0.321 & 0.405 \\
& 0.178 & 0.230 & 0.236 & 0.273 \\
& 100 & 100 & 100 & 100 \\
\hline
\end{tabular}

Standard errors are in parentheses and are adjusted for serial correlation, heteroscedasticity and dependence between observations of one PE firm.

${ }^{*}$ significant at $10 \% ;{ }^{* * *}$ significant at $5 \%$; ${ }^{* * *}$ significant at $1 \%$ 
Finally, as expected, VC funds have significantly higher percentages of loss than BO funds. Holding all other variables constant, a VC fund has a 13.5 percentage points higher fraction of losses and a 6.5 percentage points higher fraction of total losses than a BO fund, all else equal (Tables 7 and 8 , columns (3)). VC funds invest mainly in companies which are in their early stages of development. The selection process of early stage companies is characterized by a scarcity of objective information making it difficult to judge the success and survival of these companies. In comparison, established companies, which are the focus of $\mathrm{BO}$ funds, have a long history of activity. The scarcity of objective information leads to higher percentages of loss and total loss in $\mathrm{VC}$ funds relative to $\mathrm{BO}$ funds. The remaining variables do not have a significant influence on percentages of loss and total loss.

\section{Additional Robustness Checks}

This section summarizes additional analyses I undertook to determine whether the basic findings are robust.

The distributions of IRR, MIRR, and PME are right skewed. Box-Cox-transformations favor a logarithmic functional form instead of a linear functional form. Consequently, I utilized the lograithm of IRR, MIRR, and PME as dependent variables. To validate this choice, I repeated the regressions for rate of return using IRR, MIRR, and PME as dependent variables. Precision of some parameters is less. However, the results are similar with the regressions for logarithmized variables with respect to effect size and sign.

Herfindahl-Hirschman-Indices might be inappropriate to measure diversification across financing stages, industries, and countries. The effect of diversification

might not depend on the distribution of a funds' capital across various classes. Instead, it might depend only on the number of classes a PE fund invests in. In order to evaluate this assumption, I rerun all regressions using the number of financing stages, the number of industries, and the number of countries to approximate the level of 'systematic' diversification in a PE fund. The main results do not change. First, a larger number of financing stages is associated with lower rates of return 
and higher percentages of loss. Secondly, the number of industries is positively correlated with rates of return. Finally, the number of countries has no significant effect on one of the performance measures.

Analysis of selection biases has shown that the sample contains a survivorship bias. Sample funds have superior rates of return in comparison to the universe of PE funds provided by TVE. However, descriptive analysis reveals large variations of the rates of return and the levels of diversification in sample funds. Consequently, the survivorship bias is not expected to influence the relationship between diversification and performance in a way, so that it differs significantly between the sample and the population of PE funds. In order to analyze the influence of the superior performance, I exclude the upper quartile of sample funds according to gross IRR. The remaining 75 funds have an mean gross IRR of 34.9\%, mean gross MIRR of $17.0 \%$ and a mean gross PME of 2.36. Rerunning the regressions shows the following results. There is still a negative relationship between diversification across financing stages and rates of return as well as a positive relation between diversification across financing stages and percentages of loss. The effect size and significance of diversification across financing stages is identical to the regressions with all observations. Yet, the effect of diversification across industries becomes loses most of its magnitude and significance. In some specifications it even becomes negative, though not statistically significant. Hence, the top quartile of the sample funds seems to benefit more from diversification across industries than the lower three quartiles. The top quartile of sample funds are successfully able to extract return from investment opportunities in different industries.

\section{Conclusion}

The aim of this paper was to analyze the impact of diversification on the performance of $\mathrm{PE}$ funds. While the return of $\mathrm{PE}$ financing has received a tremendous amount of attention from academic researchers, the role of diversification in $\mathrm{PE}$ funds has obtained little systematic consideration. The information asymmetries and principal agent conflicts inherent in the selection and oversight of private companies suggest that PE funds specialized on specific financing stages, industries, 
or countries earn higher rates of return and lose less of their portfolio companies than diversified PE funds. Studying an unique sample of 100 PE funds containing information about 2,871 investments, a large variation across the diversification levels of PE funds are found. While some PE funds are highly specialized, others are highly diversified.

Multivariate regression analyses find only partial evidence that the rate of return of PE funds declines with 'systematic' diversification. In line with the specialization hypothesis, the rate of return of sample funds decreases with diversification across financing stages. However, in contrast to the specialization hypothesis, the rate of return of sample funds increases with diversification across industries. The benefits of additional investment opportunities in various industries appear to be higher than the costs of diversification across industries. Excluding the upper quartile of sample funds with respect to gross IRR suggests that this relationship is mainly true for the top quartile of sample funds. These funds benefit more from diversification across industries than the lower three quartiles. They are able to extract positive returns from investments in various industries. This observation backs the argumentation that PE firms should apply an opportunistic investment approach. PE firms should specialize on process know-how which is independent from specific industries or countries in order to be able to invest in any portfolio company which promises high returns regardless of their technology or country of operation. Finally, no impact of diversification across countries on rate of return of $\mathrm{PE}$ funds is found. The same is true for diversification across time. Additionally, I find rate of return of PE funds to enhance with number of portfolio companies.

Accordingly, the percentages of loss and total loss in PE funds increase with diversification across financing stages. PE firms investing in multiple financing stages seem either to fund a higher fraction of low quality companies or to give less management support compared to PE firms which invest in fewer financing stages.

Additional analyses show that the results hold for various performance measures and are robust against a change in the functional form and alternative definition of diversification across financing stages, industries, and financing stages. 
The findings have several implications for the management of and investment in PE funds. There seems to be rather limited influence of diversification on the performance of PE funds. Despite prevailing opinion, these results suggest no return premium of funds specialized on certain industries or countries compared to diversified funds. PE funds which are specialized on particular industries or countries do not seem to make superior selection decisions or to provide their portfolio companies with more value adding services than diversified PE funds. There are two complimentary explanations for this observation. First, the advantage of $\mathrm{PE}$ firms specialized on particular industries or countries to overcome the information asymmetries and principal agent problems inherent in the selection and oversight of private companies is limited. Either the specialized know-how is less important than assumed or the know-how can be purchased from specialists outside the PE firm. An alternative explanation for the result is that PE firms are specialized within their organization. Single PE managers are specialized on certain industries or countries. As a result, diversified PE firms can overcome the information asymmetries and principal agent problems inherent in the selection and oversight of private companies as well as specialized PE firms.

However, there are some caveats to consider. First, the data set used in this chapter is limited in size and biased towards larger and older BO funds with superior return in comparison to the universe of PE funds. Therefore, future research should repeat the analysis undertaken in this chapter with a larger and less biased data set. Secondly, the sample includes $100 \mathrm{PE}$ funds managed by $34 \mathrm{PE}$ firms. Some results might be caused by unobserved differences between the PE firms rather than the studied variables. Yet, the size and structure of the data set inhibit the ability to control for firm fixed effects. Finally, the measures of 'systematic' diversification are not capturing all aspects of diversification. The literature on the impact of diversification in big sized public companies find quantitative diversification measures to explain less of financial success than qualitative diversification measures (Hall \& John 1994). However, applying qualitative diversification measures similar to the relation-ratios of Rumelt on a sample of portfolio companies appears to be an unpractical task (Rumelt 1974, Rumelt 1982). For 
the sample the relation of the businesses of 2,871 portfolio companies have to be judged, demanding an unavailable amount of information and time.

To conclude, this paper is the first systematic analysis of the impact of diversification on PE funds' performance. It contributes to the growing amount of literature analyzing the investment behavior and performance of PE firms. The unique data set allowed for the first time to measure exactly the diversification of $\mathrm{PE}$ funds across various dimensions and to evaluate the relationship between these dimensions and the performance of sample funds. The results should prove to be important for both the research community as well as practitioners. 


\section{References}

AltAssets (2005), 'Glossary of private equity and venture capital terminology'. http://www.altassets.com/hm_glossary.php, December 14, 2005.

Amit, R., Brander, J. \& Zott, C. (1998), 'Why do venture capital firms exist? theory and canadian evidence', Journal of Business Venturing 13, 443-466.

Birley, S., Muzyka, D. \& Hay, M. (1999), 'Management buyout: Perception of opportunity - a research note', Journal of Management Studies 36(1), 109122.

Born, B. (2004), The risk profile of venture capital fund-of-funds, Diploma thesis, Chair of Banking of Finance, Johann Wolfgang Goethe-University, Frankfurt/Main, Germany.

Box, G. \& Cox, D. (1964), 'An analysis of transformation', Journal of the Royal Statistical Society, Series B 26, 211-243.

Chan, Y.-S. (1983), 'On the positive role of financial intermediation in allocation of venture capital in a market with imperfect information', The Journal of Finance 38(5), 1543-1568.

Cochrane, J. H. (2001), 'The risk and return of venture capital', NBER Working Paper No. 8006. January 2001.

Cochrane, J. H. (2005), 'The risk and return of venture capital', Journal of Financial Economics 75, 3-52.

Cumming, D. \& Walz, U. (2004), 'Private equity returns and disclosure around the world', Working paper, Center of Private Equity Research. March 2004, http://www.cepres.de.

Dorsey, T. (2000), 'A portfolio model for venture captal performance measurement and investment selection', Unpublished working paper. January 2000, http://www.garp.com/library/Articles/Dorsey.pdf. 
Evans, J. L. \& Archer, S. H. (1968), 'Diversification and the reduction of dispersion: An empirical analysis', The Journal of Finance 23(5), 761-767.

Gompers, P. A. (1995), 'Optimal investment, monitoring, and the staging of venture capital', The Journal of Finance 50(5), 1461-1489.

Gompers, P. A. \& Lerner, J. (2004), The Venture Capital Cycle, The MIT Press.

Gompers, P., Kovner, A., Lerner, J. \& Scharfstein, D. (2005), 'Venture capital investment cycles: the impact of public markets', NBER Working Paper No. 11385. May 2005.

Gompers, P. \& Lerner, J. (2000), 'Money chasing deals? the impact of fund inflows on private equity valuations', Journal of Financial Economics 55, 281-325.

Gorman, M. \& Sahlman, W. A. (1989), 'What do venture capitalists do?', Journal of Business Venturing 4, 231-248.

Gottschalg, O., Phalippou, L. \& Zollo, M. (2004), 'Performance of private equity funds: Another puzzle?', Working paper, INSEAD-Wharton Alliance Center for Global Research \& Development. September 2004.

Gupta, A. K. \& Sapienza, H. J. (1992), 'Determinants of venture capital firms' preferences regarding the industry diversity and geographic scope of their investments', Journal of Business Venturing 7, 347-362.

Hall, E. H. \& John, C. H. (1994), 'A methodological note on diversity measurement', Strategic Management Journal 15(2), 153-168.

Hege, U., Palomino, F. \& Schwienbacher, A. (2003), 'Determinants of venture capital performance: Europe and the United States', Working paper, HEC School of Management. January 2003.

Hellmann, T. \& Puri, M. (2001), 'The interaction between product market and financing strategy: The role of venture capital', Review of Financial Studies 13, 959-984. 
Hellmann, T. \& Puri, M. (2002), 'Venture capital and the professionalization of start-up firms: Empirical evidence', The Journal of Finance 57, 169-197.

Ick, M. (2005), 'Performance measurement and appraisal of private equity investments relative to public equity markets', Working paper, Center of Private Equity Research. May 2005, http://www.cepres.de.

Jones, C. M. \& Rhodes-Kropf, M. (2003), 'The price of diversifiable risk in venture capital and private equity', Working paper, Columbia University Graduate School of Business. May 2003.

Kaplan, S. N. \& Strömberg, P. (2000), 'Financial contracting theory meets the real world: An empirical analysis of venture capital contracts', Review of Economic Studies 70, 281-315.

Kaplan, S. \& Schoar, A. (2003), 'Private equity performance: Returns, persistence and capital flows', NBER Working Paper No. 9807. June 2003.

Kaplan, S. \& Schoar, A. (2005), 'Private equity performance: Returns, persistence and capital flows', Journal of Finance 60(4), 1791-1823.

Kaserer, C. \& Diller, C. (2004a), 'Beyond irr once more', Private Equity International (July/August).

Kaserer, C. \& Diller, C. (2004b), 'What drives cash flow based european private equity returns? - fund inflows, skilled gps, and/or risk?', Working paper, Center for Entrepreneurial and Financial Studies, Technical University Munich. November 2004.

Ljungqvist, A. \& Richardson, M. (2003a), 'The cash flow, return and risk characteristics of private equity', NBER Working Paper No. 9454. January 2003.

Ljungqvist, A. \& Richardson, M. (2003b), 'The investment behavior of private equity fund managers', RICAFE Working Paper No. 005. October 2003.

MacMillan, I., Zemann, L. \& Subbanarasimha, P. (1987), 'Criteria distinguishing successful from unsuccessful ventures in the venture screening process', Journal of Business Venturing 2, 123-137. 
Neter, J., Wasserman, W. \& Kutner, M. H. (1990), Applied Linear Statistical Models: Regression, Analysis of Variance, and Experimental Designs, Irwin, Homewood/Boston.

Norton, E. \& Tenebaum, B. H. (1993), 'Specialization versus diversification as a venture capital investment strategy', Journal of Business Venturing 8, 431442.

Rogers, W. (1993), 'Regression standard errors in clustered samples', Stata Technical Bulletin Reprints 3, 88-94.

Rumelt, R. P. (1974), Strategy, Structure, and Economic Performance, Harvard University Press, Boston.

Rumelt, R. P. (1982), 'Diversification strategy and profitability', Strategic Management Journal 3, 359-369.

Sahlman, W. A. (1990), 'The structure and governance of venture-capital organizations', Journal of Financial Economics 27, 473-524.

Schmidt, D. (2004), 'Private equity-, stock- and mixed asset-portfolios: A bootstrap approach to determine performance characteristics, diversification benefits and optimal portfolio allocations', Working paper, Center of Private Equity Research. December 2004, http://www.cepres.de.

Thomson Venture Economics (2005), 'Glossary', Website. http://www.ventureeconomics.com/vec/glossary.html, December 14, 2005.

Tyebjee, B. \& Bruno, A. (1984), 'A model of venture capitalist investment activity', Management Science 30(9), 1051-1066.

Weidig, T. \& Mathonet, P.-Y. (2004), 'The risk profiles of private equity', EIF Working paper. January 2004.

White, H. (1980), 'A heteroskedasticity-consistent covariance matrix estimator and a direct test for heteroskedasticity', Econometrica 48(4), 817-830. 
Zimmerman, H., Bilo, S., Christiophers, H. \& Degosciu, M. (2005), 'Risk, returns, and biases of listed private equity portfolios', University of Basel, WWZ, Department of Finance, WWZ Working Paper No.1-05. April 2005. 


\section{A Appendix}

Figure 1: Distribution of sample across vintage years

The Figure shows the distribution of observations across vintage years. The sample contains 100 PE funds with vintage years between 1979 and 1998. PE funds are divided into liquidated and active funds. Active funds have a NAV larger than zero. Liquidated funds have no NAV any more. Vintage year is defined as the year of the first investment of a fund.

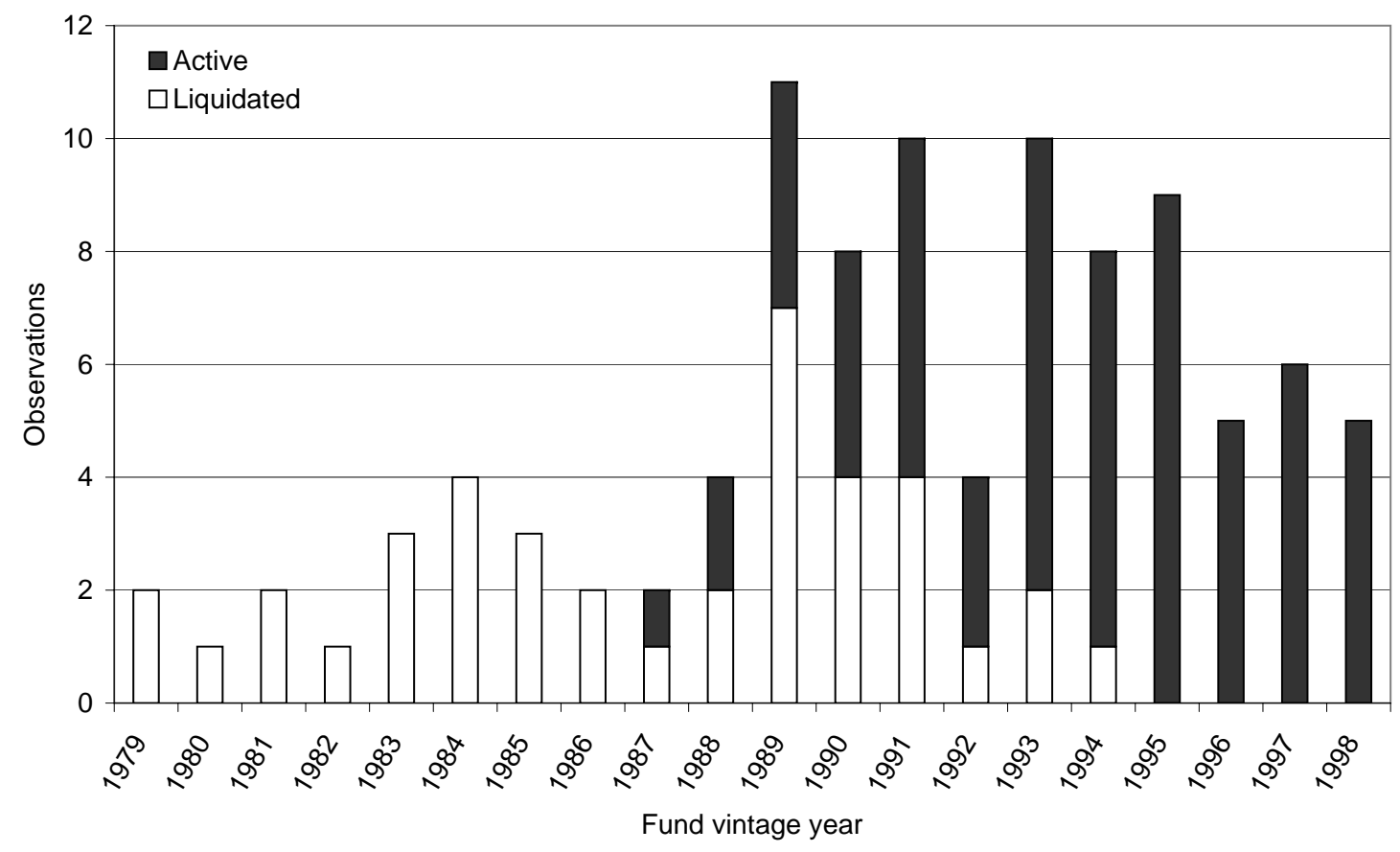




\section{Figure 2: Histograms of performance measures}

The sample contains $100 \mathrm{PE}$ funds. The Figure shows histograms of the performance measures. Panel A includes histograms of IRR, MIRR, and PME. Panel B displays histograms of percentage of loss and total loss. The y-axis is scaled so that the sum of the bars' areas equals one.

\section{Panel A: Rate of return}
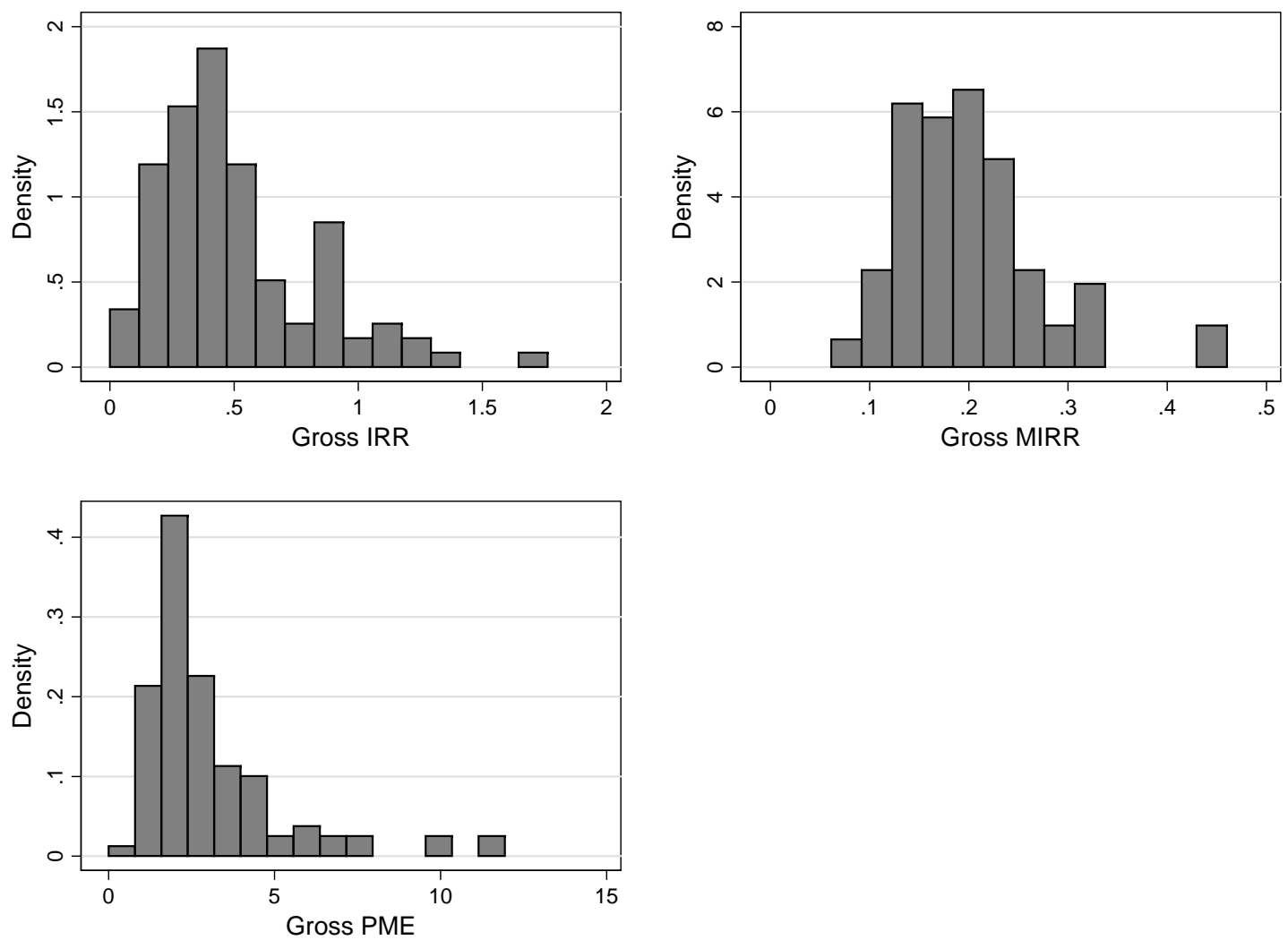

Panel B: Percentage of loss
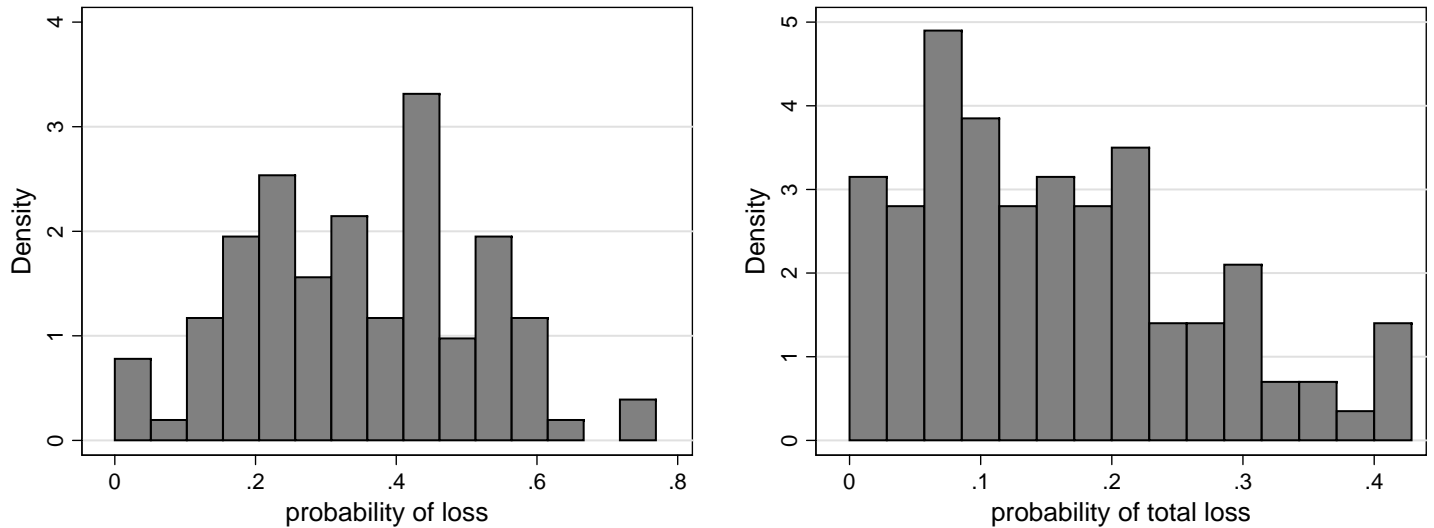


\section{Table 9: Mathematical definition of rate of return}

Internal rate of return $(I R R)$

$$
0=\sum_{t=0}^{T}\left(\frac{\sum_{i=1}^{N} C F_{i t}}{(1+I R R)^{t}}\right)
$$

with $C F_{i t}=$ cash flow of portfolio company $\mathrm{i}$ in period $\mathrm{t}$.

Modified internal rate of return (MIRR)

$$
M I R R=\sqrt[T]{\frac{\sum_{t=0}^{T}\left[\left(\sum_{i=1}^{N} C F_{i t}\right) \cdot(1+r)^{T-t} \cdot p_{t}\right]}{\sum_{t=0}^{T}\left[\left(\sum_{i=1}^{N} C F_{i t}\right) \cdot(1+r)^{-t} \cdot n_{t}\right]}}
$$

with $r=$ discount rate for interim cash flows,

$$
\begin{aligned}
& p_{t}= \begin{cases}1 & \text { if in period t } \sum_{i=1}^{N} C F_{i t} \geq 0 \\
0 & \text { else, }\end{cases} \\
& n_{t}= \begin{cases}1 & \text { if in period } \mathrm{t} \sum_{i=1}^{N} C F_{i t}<0 \\
0 & \text { else. }\end{cases}
\end{aligned}
$$

Public market equivalent (PME)

$$
P M E=\frac{\sum_{t=0}^{T}\left[\left(\sum_{i=1}^{N} C F_{i t}\right) /\left(\prod_{k=0}^{t}\left(1+r_{k}\right)\right) \cdot p_{t}\right]}{\sum_{t=0}^{T}\left[\left(\sum_{i=1}^{N} C F_{i t}\right) /\left(\prod_{l=0}^{t}\left(1+r_{l}\right)\right) \cdot n_{t}\right]}
$$

with $r_{k}, r_{l}=$ discrete return of the public market index in period $\mathrm{k}$ or $\mathrm{l}$,

$$
\begin{aligned}
& p_{t}= \begin{cases}1 & \text { if in period t } \sum_{i=1}^{N} C F_{i t} \geq 0 \\
0 & \text { else, }\end{cases} \\
& n_{t}= \begin{cases}1 & \text { if in period } \mathrm{t} \sum_{i=1}^{N} C F_{i t}<0 \\
0 & \text { else. }\end{cases}
\end{aligned}
$$




\section{Table 10: Definition of financing stages}

To measure diversification across financing stages, each portfolio company was assigned to a financing stage. In order to do so, the following definitions were used

- Venture capital: The term $\mathrm{VC}$ is used to describe the provision of equity or equity linked capital to young, high growth companies which have a limited history of operation (Gompers \& Lerner 2004). According to the status of operation, VC is divided into (AltAssets 2005, Thomson Venture Economics 2005):

- Seed / early stage venture capital: Seed capital refers to the provision of very early stage finance to a company which has not yet been established. Seed capital is often provided before venture capitalists become involved. Early stage VC is provided to companies which have been recently established. It is used for product development, as well as initial marketing, manufacturing and sales activities.

- Expansion / second stage venture capital: It is provided for the first expansion of a company, which is already in production and shipment. The company is experiencing growth in inventory and accounts receivable.

- Later / third stage venture capital: The term denominates funding of a company, which has sTable operations and is breaking even or profiTable. The capital is used for further growth of the company.

- Buyout capital: A BO is the purchase of a company or a controlling interest of a corporation's shares or some part of business (AltAssets 2005). The focus of BO capital are mature companies with a proven track record. Various types of BOs can be divided emphasizing each one important element of the transaction. The most important are leveraged $\mathrm{BO}(\mathrm{LBO})$, management $\mathrm{BO}(\mathrm{MBO})$, management buyin $(\mathrm{MBI})$, recapitalization, and turnaround. The majority of classifications also assign mezzanine financing to $\mathrm{BO}$ capital because it is mostly used in $\mathrm{BO}$ transactions.

- Listed securities: In some cases PE firms buy shares of companies which are listed on public stock exchanges. Often these companies have been funded by the same PE firm years ago in a private transaction.

- Other financing stage: The category other financing stage was used for companies, which did not fit in one of the other categories. 
Table 11: Classification of portfolio companies

Each portfolio company was assigned to a financing state, an industry, and a country. The Table displays the distribution of portfolio companies across the three classifications.

\begin{tabular}{lcr}
\hline & Panel A: Financing stages & \\
\hline & \# of portfolio companies & $\%$ \\
\hline Seed / early stage venture capital & 877 & 30.68 \\
Second, expansion and later stage venture capital & 1,057 & 36.97 \\
Buyout & 882 & 30.85 \\
Listed securities & 13 & 0.45 \\
Other financing stage & 30 & 1.05 \\
\hline All portfolio companies & 2,859 & 100.00 \\
\hline & & \\
\hline & Panel B: Industries & \\
\hline Internet and Computer & of portfolio companies & 31.43 \\
Communications and Electronics & 862 & 14.59 \\
Business and Industrial & 400 & 8.93 \\
Consumer, & 245 & 11.60 \\
Energy and Utilities & 318 & 2.08 \\
Biotechnology and Healthcare & 57 & 19.33 \\
Financial Services & 530 & 5.00 \\
Business Services & 137 & 6.42 \\
Other & 176 & 0.62 \\
\hline All portfolio companies & 17 & 100.00 \\
\hline
\end{tabular}


Table 11 - Continued

\begin{tabular}{|c|c|c|}
\hline \multicolumn{3}{|c|}{ Panel B: Countries } \\
\hline Country & \# of portfolio companies & $\%$ \\
\hline Argentina & 1 & 0.03 \\
\hline Austria & 2 & 0.07 \\
\hline Belgium & 4 & 0.14 \\
\hline Bermuda & 3 & 0.10 \\
\hline Brazil & 2 & 0.07 \\
\hline Canada & 25 & 0.87 \\
\hline China & 5 & 0.17 \\
\hline Czech Republic & 1 & 0.03 \\
\hline Denmark & 7 & 0.24 \\
\hline France & 139 & 4.84 \\
\hline Germany & 101 & 3.52 \\
\hline Hong Kong & 4 & 0.14 \\
\hline Iceland & 2 & 0.07 \\
\hline India & 2 & 0.07 \\
\hline Indonesia & 4 & 0.14 \\
\hline Israel & 21 & 0.73 \\
\hline Italy & 52 & 1.81 \\
\hline Japan & 1 & 0.03 \\
\hline Malaysia & 1 & 0.03 \\
\hline Netherlands & 14 & 0.49 \\
\hline Norway & 1 & 0.03 \\
\hline Philippines & 2 & 0.07 \\
\hline Poland & 1 & 0.03 \\
\hline Portugal & 1 & 0.03 \\
\hline Republic of Ireland & 6 & 0.21 \\
\hline Romania & 1 & 0.03 \\
\hline Singapore & 2 & 0.07 \\
\hline Spain & 11 & 0.38 \\
\hline Sweden & 18 & 0.63 \\
\hline Switzerland & 12 & 0.42 \\
\hline Taiwan & 2 & 0.07 \\
\hline Thailand & 1 & 0.03 \\
\hline United Kingdom & 306 & 10.66 \\
\hline United States of America & 2,116 & 73.70 \\
\hline All portfolio companies & 2,871 & 100.00 \\
\hline
\end{tabular}




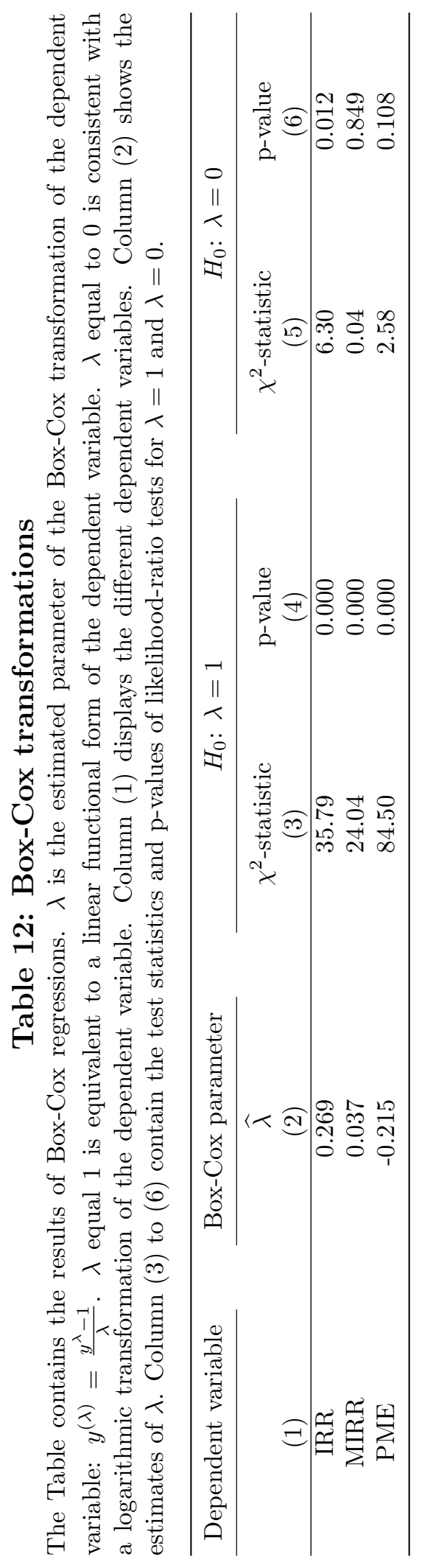




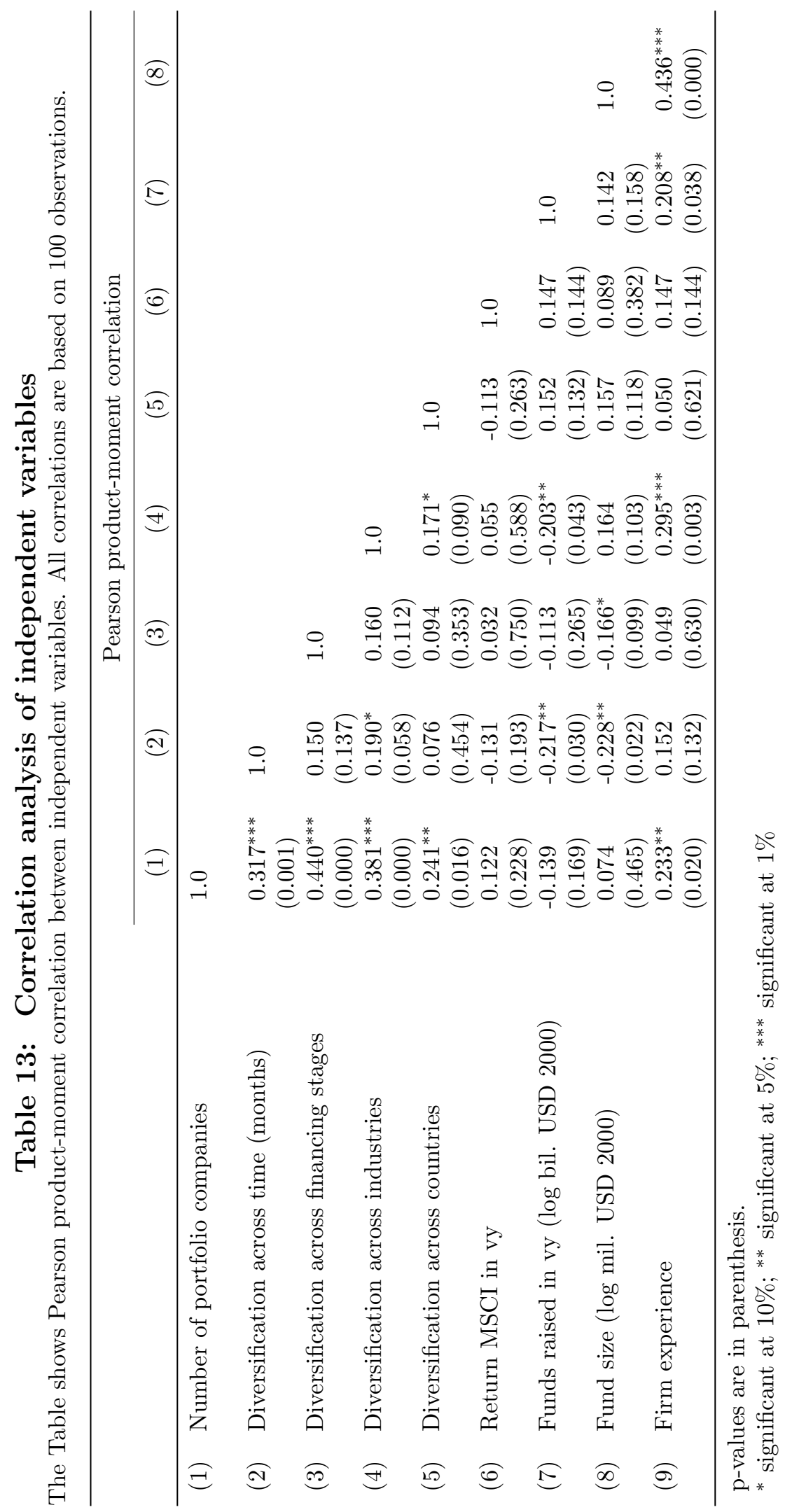




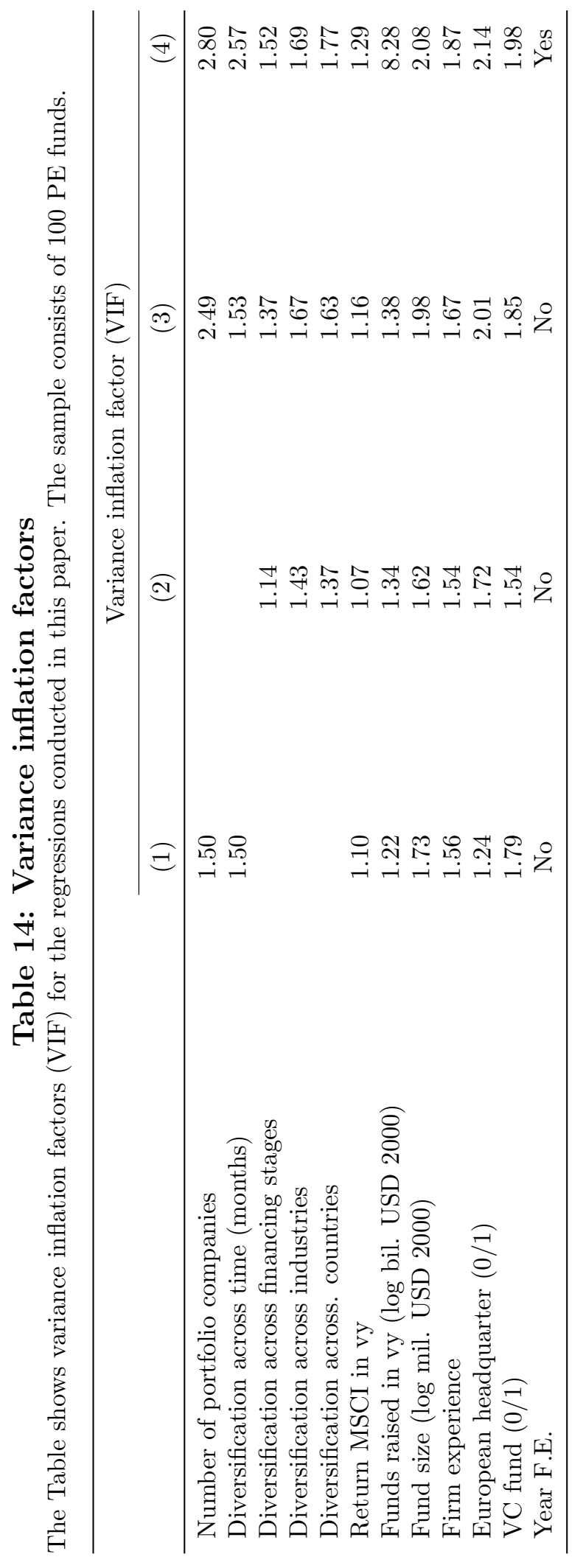

